\title{
The carbon cycle in the Australian Community Climate and Earth System Simulator (ACCESS-ESM1) - Part 1: Model description and pre-industrial simulation
}

\author{
Rachel M. Law ${ }^{1}$, Tilo Ziehn ${ }^{1}$, Richard J. Matear ${ }^{2}$, Andrew Lenton ${ }^{2}$, Matthew A. Chamberlain ${ }^{2}$, Lauren E. Stevens ${ }^{1}$, \\ Ying-Ping Wang ${ }^{1}$, Jhan Srbinovsky ${ }^{1}$, Daohua Bi ${ }^{1}$, Hailin Yan ${ }^{1, a}$, and Peter F. Vohralik ${ }^{3}$ \\ ${ }^{1}$ CSIRO Oceans and Atmosphere, PMB 1, Aspendale, Victoria, Australia \\ ${ }^{2}$ CSIRO Oceans and Atmosphere, Hobart, Tasmania, Australia \\ ${ }^{3}$ CSIRO Manufacturing, Lindfield, New South Wales, Australia \\ ${ }^{a}$ now at: Bureau of Meteorology, Melbourne, Australia
}

Correspondence to: Rachel M. Law (rachel.law@csiro.au)

Received: 30 June 2015 - Discussion started: 18 September 2015

Revised: 25 January 2017 - Accepted: 10 May 2017 - Published: 6 July 2017

\begin{abstract}
Earth system models (ESMs) that incorporate carbon-climate feedbacks represent the present state of the art in climate modelling. Here, we describe the Australian Community Climate and Earth System Simulator (ACCESS)-ESM1, which comprises atmosphere (UM7.3), land (CABLE), ocean (MOM4p1), and sea-ice (CICE4.1) components with OASIS-MCT coupling, to which ocean and land carbon modules have been added. The land carbon model (as part of CABLE) can optionally include both nitrogen and phosphorous limitation on the land carbon uptake. The ocean carbon model (WOMBAT, added to MOM) simulates the evolution of phosphate, oxygen, dissolved inorganic carbon, alkalinity and iron with one class of phytoplankton and zooplankton. We perform multi-centennial preindustrial simulations with a fixed atmospheric $\mathrm{CO}_{2}$ concentration and different land carbon model configurations (prescribed or prognostic leaf area index). We evaluate the equilibration of the carbon cycle and present the spatial and temporal variability in key carbon exchanges. Simulating leaf area index results in a slight warming of the atmosphere relative to the prescribed leaf area index case. Seasonal and interannual variations in land carbon exchange are sensitive to whether leaf area index is simulated, with interannual variations driven by variability in precipitation and temperature. We find that the response of the ocean carbon cycle shows reasonable agreement with observations. While our model overestimates surface phosphate values, the global pri-
\end{abstract}

mary productivity agrees well with observations. Our analysis highlights some deficiencies inherent in the carbon models and where the carbon simulation is negatively impacted by known biases in the underlying physical model and consequent limits on the applicability of this model version. We conclude the study with a brief discussion of key developments required to further improve the realism of our model simulation.

\section{Introduction}

Over recent decades many climate models have evolved into Earth system models (ESMs), a term used to identify models that simulate biogeochemical cycles and their interaction with human and climate systems. Of principal concern is the carbon cycle. Anthropogenic emissions of carbon lead to increased concentrations of atmospheric carbon dioxide $\left(\mathrm{CO}_{2}\right)$. This directly impacts uptake of carbon by the land and ocean systems and warms the climate. Climate warming, in turn, perturbs the carbon uptake, typically leading to reduced carbon uptake and a positive feedback on warming. This climate-carbon feedback was first explored by Cox et al. (2000) and Friedlingstein et al. (2001) and compared across models in Friedlingstein et al. (2006). This model intercomparison confirmed that all models gave a positive 
carbon-climate feedback but the magnitude of that feedback was very variable across models.

While ESM simulations with the full carbon cycle and an interactive atmosphere ("emissions-driven simulations") are essential for quantifying the carbon-climate feedbacks, simulations with a fixed atmospheric $\mathrm{CO}_{2}$ ("concentrationdriven") are also valuable. These simulations are used to diagnose land and ocean carbon exchange with the atmosphere based on a prescribed atmospheric history of $\mathrm{CO}_{2}$ and any associated climate impacts of those atmospheric $\mathrm{CO}_{2}$ changes. Thus, the temporal evolution of carbon exchange can be evaluated for a range of future atmospheric $\mathrm{CO}_{2}$ trajectories. This simpler concentration-driven mode for ESM simulations removes any direct impact of the carbon cycle on the climate simulation with indirect impacts only occurring through possible changes to the land surface characteristics such as the leaf area index.

The Coupled Model Intercomparison Project (CMIP5) (Taylor et al., 2012) included additional model output from concentration-driven simulations and extra emissions-driven simulations for those models that could simulate the carbon cycle. Evaluations were conducted of the concentrationdriven model-simulated carbon fluxes over the historical period (Anav et al., 2013) and the relationship of land carbon fluxes to different climate variables (Shao et al., 2013). Future carbon fluxes were compared across models for simulations with prescribed atmospheric $\mathrm{CO}_{2}$ (Jones et al., 2013) and emissions-driven simulations (Friedlingstein et al., 2014). The range of results for the emissions-driven simulations was similar to that found by Friedlingstein et al. (2006) with the main cause of the large range being differences in the land carbon cycle projections. Feedback analysis was conducted by Boer and Arora (2012) and Arora et al. (2013).

The Australian Community Climate and Earth System Simulator (ACCESS) has been developed over recent years to meet both the numerical weather prediction (Puri et al., 2013) and climate simulation needs (Bi et al., 2013b) of the Australian Bureau of Meteorology, CSIRO and Australian university researchers. For climate needs, the initial aim was to put together a physical coupled climate model for participation in CMIP5. A second aim is to add the carbon cycle and implement an atmospheric chemistry scheme. Two versions of ACCESS participated in CMIP5 (Dix et al., 2013), ACCESS1.0 and ACCESS1.3 (Bi et al., 2013b), differing in their atmosphere model settings and land surface scheme. Development of the Earth system version of ACCESS, denoted ACCESS-ESM1, is based on the ACCESS1.4 physical climate model, an updated version of ACCESS1.3 (Fig. 1).

This paper documents the components of ACCESS-ESM1 (Fig. 1), relative to previously published versions. Thus, we note the relatively minor physical model differences between ACCESS1.3 and ACCESS1.4 (Appendix A) as well as the addition of the carbon components to ACCESS (Sect. 2.2, 2.3, 2.4), to give the current ESM configuration. The model configuration and model inputs required to run
CMIP5-type carbon simulations are presented in Sect. 3. Evaluation of the ACCESS-ESM1 model is divided between this paper and part 2 of this study (Ziehn et al., 2017).

Here we focus on simulations under pre-industrial conditions and prescribed atmospheric $\mathrm{CO}_{2}$, which should allow the simulated carbon cycle to equilibrate and provides the simplest case for a first evaluation of the model performance. Two land carbon configurations are compared, using prescribed or prognostic leaf area index (LAI). These were chosen because simulating LAI will have an impact on the climate simulation even with prescribed atmospheric $\mathrm{CO}_{2}$ (Sect. 4.1). We then characterize the simulated carbon cycle behaviour, focussing on flux equilibration (Sect. 4.2), sensitivity to the simulation configuration (Sects. 4.3 and 4.4) and variability (Sect. 4.5). In Ziehn et al. (2017), evaluation is for a concentration-driven historical simulation (1850-2005), allowing for comparison with present-day observations and other models. ACCESS-ESM1 simulations for future periods (2005-2100) will be presented elsewhere.

\section{ACCESS-ESM1 model description}

ACCESS-ESM1 comprises the ACCESS1.4 physical climate model (Sect. 2.1), with new capability to simulate the carbon cycle. Land carbon fluxes (Sect. 2.2) are simulated as part of the Community Atmosphere Biosphere Land Exchange (CABLE) model, which includes a module to simulate carbon exchange between land carbon pools, with the optional inclusion of nutrient limitation. Ocean carbon fluxes (Sect. 2.3) are simulated by the World Ocean Model of Biogeochemistry And Trophic-dynamics (WOMBAT). Versions of CABLE and WOMBAT have been documented previously (e.g. Kowalczyk et al., 2006; Oke et al., 2013). Hence, the descriptions below are mostly limited to any model developments since the earlier work and specifics of the model implementation in the ACCESS-ESM1 context. The focus is on the carbon fluxes from the land and ocean that are input to the atmosphere (Sect. 2.4), either actively influencing climate through the atmospheric $\mathrm{CO}_{2}$ field or as passive tracers for comparison with observed atmospheric $\mathrm{CO}_{2}$.

\subsection{Physical model: ACCESS1.4}

The physical model to which we are adding the carbon cycle is designated ACCESS1.4. As shown in Fig. 1, the atmospheric component of ACCESS1.4 is the UK Met Office Unified Model (UM) (Martin et al., 2010; The HadGEM2 Development Team, 2011) to which the land surface model, CABLE, is directly coupled; the ocean component is a version of the NOAA/GFDL Modular Ocean Model (MOM4p1) (Griffies, 2009) and sea ice is modelled using the LANL CICE4.1 model (Hunke and Lipscomb, 2010) with coupling of the ocean and sea ice to the atmosphere with the OASIS coupler (Valcke, 2013). The ACCESS configuration of the 


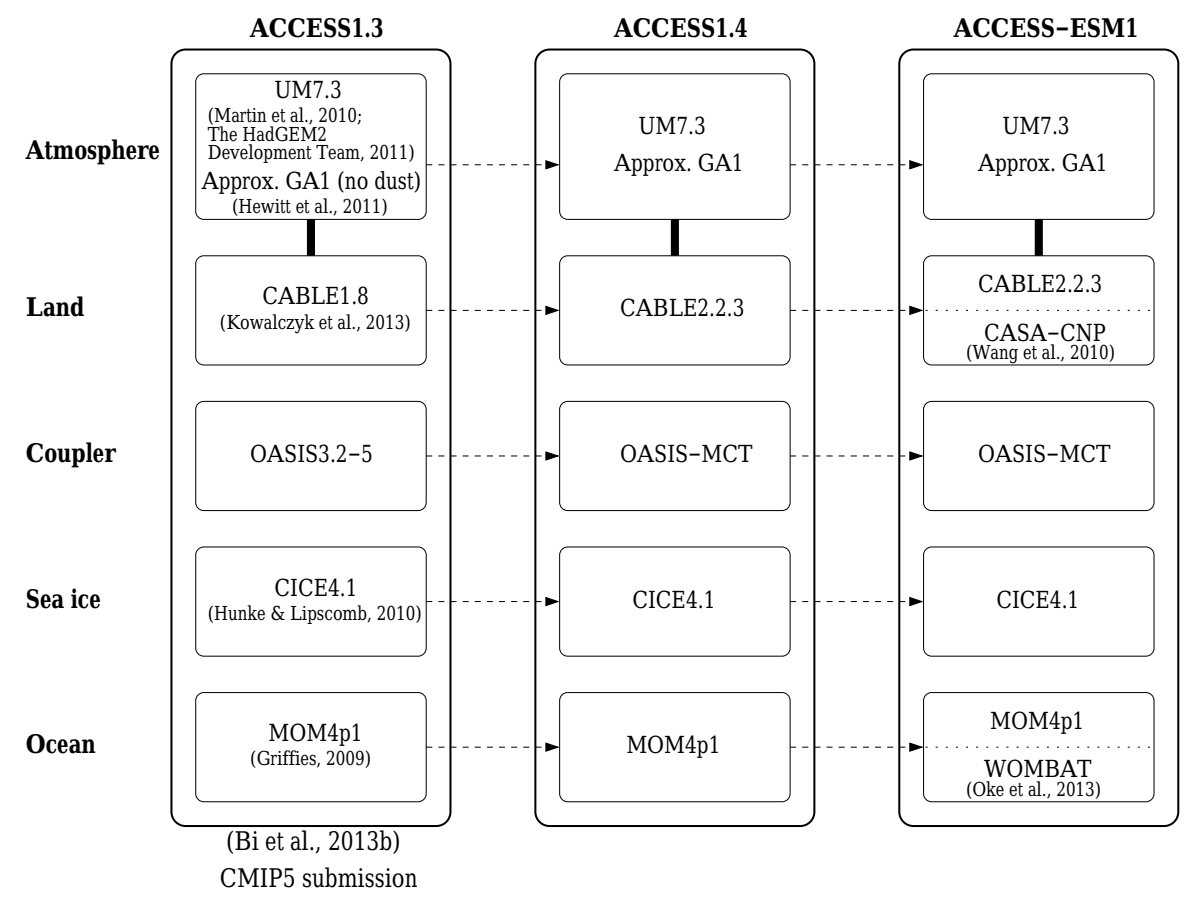

Figure 1. Schematic showing the different component models of ACCESS-ESM1 and the ACCESS versions on which it is dependent.

ocean and sea-ice components, ACCESS-OM, is described in Bi et al. (2013a) with CMIP5 evaluations documented in Marsland et al. (2013) and Uotila et al. (2013). The oceanonly configuration of ACCESS has been extensively used to explore intrinsic variability in the ocean and the role it may play in decadal variability (e.g. O'Kane et al., 2013).

ACCESS1.4 is a minor upgrade from ACCESS1.3, which was used for CMIP5 and extensively documented (e.g. Bi et al., 2013b; Dix et al., 2013; Kowalczyk et al., 2013). ACCESS1.4 addresses a number of issues that were identified during the analysis of the ACCESS1.3 CMIP5 simulations and also includes an updated version of CABLE (CABLE2). Details of changes to the physical model between ACCESS1.3 and ACCESS1.4 are given in Appendix A.

\subsection{Land carbon model: CABLE}

CABLE is a land surface model that simulates the fluxes of momentum, heat, water and carbon across the landatmosphere interface. CABLE operates both in stand-alone mode (forced with prescribed meteorology) and coupled to atmospheric models (at least five different models to date, both global and regional). The history and scientific core of CABLE version 1 is most fully described in Kowalczyk et al. (2006) with a summary description provided in the Appendix of Wang et al. (2011). ACCESS1.4 and ACCESS-ESM1 use CABLE2.2.3 (Fig. 1). CABLE version 2 was designed to provide a consolidation of the stand-alone and ACCESS versions of CABLE into a single code repository with common science routines. In particular, this enabled the ACCESS ver- sion to optionally run with a biogeochemical module (Wang et al., 2010), which was initially developed for the standalone version.

In ACCESS, CABLE is run for one or more tiles in each grid cell with a non-zero land fraction. Each tile represents a different vegetated or non-vegetated surface type with a number of CABLE input parameters being surfacetype dependent (Sect. 3.1.1). Each tile is modelled with a separate soil column beneath the surface. The biogeochemistry module, denoted CASA-CNP, simulates the flow of carbon, and optionally, nitrogen and phosphorus between three plant biomass pools (leaf, wood, root), three litter pools (metabolic, structural, coarse woody debris) and three organic soil pools (microbial, slow, passive), one inorganic soil mineral nitrogen pool and three other phosphorus soil pools (labile, sorbed, strongly sorbed).

The flux of carbon from the land to the atmosphere has two components, net ecosystem exchange (NEE) and fluxes due to disturbance (e.g. fire) and land use change. Currently, CABLE simulates the former but not the latter.

Gross primary production (GPP) and leaf maintenance respiration are calculated every time step using a two-leaf (sunlit and shaded) canopy scheme (Wang and Leuning, 1998).

$\mathrm{GPP}=f\left(\mathrm{LAI}, v_{\mathrm{cmax}}, j_{\max }\right)$,

where LAI is leaf area index, $v_{\mathrm{cmax}}$ is the maximum rate of carboxylation and $j_{\max }$ is the maximum rate of potential electron transport. LAI may be prescribed or simulated, with simulated (prognostic) LAI being dependent on the size of the leaf carbon pool $\left(c_{\text {leaf }}\right)$ and the specific leaf area (SLA), 
which is a vegetation-dependent parameter:

$\mathrm{LAI}=\max \left(\mathrm{LAI}_{\min }, c_{\text {leaf }} \times \mathrm{SLA}\right)$,

where the max function ensures a vegetation-dependent minimum LAI $\left(\mathrm{LAI}_{\min }\right)$. Section 4.2.1 notes an unintended impact of this minimum LAI constraint. $v_{\mathrm{cmax}}$ and $j_{\max }$ are vegetation-dependent parameters for carbon-only simulations, but when nutrient limitation is active, $v_{\mathrm{cmax}}$ and $j_{\max }$ become dependent on leaf nitrogen ( $\left.n_{\text {leaf }}\right)$ and phosphorus to nitrogen ratio $\left(p_{\mathrm{n}}\right)$ (Zhang et al., 2013; Wang et al., 2012):

$v_{\text {cmax }}=\left(a+b f\left(p_{\text {n }}\right) n_{\text {leaf }}\right) \times c$

$j_{\max }=2 v_{\text {cmax }}$,

where $a$ and $b$ are vegetation-type-dependent empirical coefficients taken from Kattge et al. (2009) and $c$ is effectively used as a tuning parameter (Table $\mathrm{S} 1$ in the Supplement). For evergreen broadleaf forest $f\left(p_{\mathrm{n}}\right)$ is expressed as

$f\left(p_{\mathrm{n}}\right)=0.4+9 p_{\mathrm{n}}$

and set to one for other vegetation types due to the lack of data (Zhang et al., 2013).

Daily mean GPP and leaf respiration are passed into the biogeochemical module, which is run once per day to calculate the remaining respiration fluxes and the carbon flow between pools. The fractions of GPP allocated to each vegetation pool are vegetation-dependent parameters, which, for non-evergreen vegetation types, are also dependent on leaf phenology phase (Wang et al., 2010). The phenology phase is prescribed by latitude and vegetation type and is based on remote sensing data (Zhang et al., 2004, 2005).

Maintenance respiration of woody tissue and roots and growth respiration are calculated as a function of mean daily air temperature and tissue nitrogen amount. Default carbon to nitrogen and nitrogen to phosphorus ratios are used when nitrogen and/or phosphorus are not simulated. Growth respiration is calculated daily as a proportion of the difference between daily GPP and plant maintenance respiration, with the proportion being a function of leaf nitrogen to phosphorus ratio (Zhang et al., 2013). Microbial respiration from decomposition of litter and soil carbon is also calculated daily and depends on the amount of organic carbon (or substrate quantity), the nitrogen to carbon ratio of organic carbon in litter or soil (substrate quality), and soil temperature and moisture (Kelly et al., 2000). We used a Q10-type function to describe the dependence of microbial respiration on soil temperature, although other functions can also be used (Exbrayat et al., 2013).

Since plant and soil respiration rates are only calculated daily, CABLE in ACCESS-ESM1 is not expected to realistically simulate the diurnal cycle of the net land carbon flux to the atmosphere, and we restrict our analysis to monthly or longer timescales.
CABLE with CASA-CNP has been used in a number of offline applications, where meteorological forcing is prescribed, (e.g. Huang et al., 2015) as well as in a lowresolution Earth system model in atmosphere-only simulations (Zhang et al., 2011, 2013; Wang et al., 2015) or in atmosphere-ocean coupled simulations (Zhang et al., 2014). Experience from these studies has guided configuration and parameter choices for CABLE in ACCESS-ESM1 (Sect. 3).

\subsection{Ocean carbon model: WOMBAT}

The WOMBAT model is based on a NPZD (nutrient, phytoplankton, zooplankton and detritus) model with the additions of bio-available iron limitation (Fe), dissolved inorganic carbon (DIC), calcium carbonate $\left(\mathrm{CaCO}_{3}\right)$, alkalinity (ALK) and oxygen $(\mathrm{O})$. At present WOMBAT includes only one class each of phytoplankton and zooplankton. All biogeochemical (BGC) tracers are calculated on the same grid as temperature. The equations of WOMBAT are given in Oke et al. (2013, Appendix B) and the parameters used in this simulation are given in Table 1. In our simulations our nutrient is phosphate and hence we do not explicitly simulate the nitrogen cycle.

In this model we include two DIC tracers: natural and anthropogenic DIC. These two DIC tracers only differ in the atmospheric $\mathrm{CO}_{2}$ concentration used in the air-sea flux calculation. For the natural DIC, the atmospheric $\mathrm{CO}_{2}$ was kept at $285 \mathrm{ppm}$ while for anthropogenic DIC the atmospheric $\mathrm{CO}_{2}$ increases according to the historical or future atmosphere concentration. At the surface we calculate the airsea exchange of the two carbon tracers and oxygen following Lenton and Matear (2007), which uses the difference in partial pressure between the ocean and atmosphere, the simulated sea-ice concentrations, and the wind speed squared and temperature-dependent gas exchange coefficient following Wanninkhof (1992). We used the OCMIP3 protocol to compute ocean $p \mathrm{CO}_{2}$ from the simulated temperature, salinity, phosphate, DIC and ALK fields. WOMBAT simulates the biological production and export of particulate organic carbon (detritus) and calcium carbonate from the photic zone and its subsequent remineralization in the ocean interior. The remineralization of particulate organic matter occurs through prescribed remineralization and sinking rates. The model maintains particulate organic matter and calcium carbonate sediment pools so that any particulate material reaching the sediments is remineralized back into the overlying water at the same remineralization rate as the water column values. The sediment pools are included to improve numerical stability of the ocean carbon module by preventing the instantaneous remineralization of particulate material in the deepest layer of the model. 
Table 1. Model Parameters of the BGC model were set to the values optimized in the one-dimensional (1-D) model of the Southern Ocean (Oschlies and Schartau, 2005).

\begin{tabular}{llr}
\hline Parameter & Units & Value \\
\hline Phytoplankton model parameters & & \\
\hline Initial slope of P-I curve & $\mathrm{d}^{-1}\left(\mathrm{~W} \mathrm{~m}^{-2}\right)^{-1}$ & 0.256 \\
Photosynthetically active radiation & - & 0.43 \\
Maximum growth rate parameters & $\mathrm{d}^{-1},-, \mathrm{C}^{-1}$ & $0.27,1.066,1.0$ \\
Half saturation constant for $\mathrm{N}$ uptake & $\mathrm{mmol} \mathrm{N} \mathrm{m}^{-3}$ & 0.7 \\
Half saturation constant for Fe uptake & $\mu$ mol Fe m & \\
Phytoplankton mortality & $\mathrm{d}^{-1}$ & 0.1 \\
Quadratic mortality & $\left(\mathrm{mmol} \mathrm{N} \mathrm{m}^{-3}\right)^{-1} \mathrm{~d}^{-1}$ & $0.04 b^{\mathrm{cT}}$ \\
\hline Zooplankton model parameters & & 0.25 \\
\hline Assimilation efficiency & - & \\
Maximum grazing rate & $\mathrm{d}^{-1}$ & 0.925 \\
Prey capture rate & $\left(\mathrm{mmol} \mathrm{N} \mathrm{m}^{-2}\right)^{-1} \mathrm{~d}^{-1}$ & 1.575 \\
Quadratic mortality & $\left(\mathrm{mmol} \mathrm{N} \mathrm{m}^{-3}\right)^{-1} \mathrm{~d}^{-1}$ & 1.6 \\
Excretion & $\mathrm{d}^{-1}$ & 0.34 \\
\hline Detritus model parameters & & $0.01 b^{\mathrm{cT}}$ \\
\hline Remineralization rate $(<180 \mathrm{~m})$ & $\mathrm{d}^{-1}$ & \\
Remineralization rate $(\geq 180 \mathrm{~m})$ & $\mathrm{d}^{-1}$ & $0.048 b^{\mathrm{cT}}$ \\
Sinking velocity & $\mathrm{m} \mathrm{d}^{-1}$ & $0.024 b^{\mathrm{cT}}$ \\
\hline CaCO 3 model parameters & & 18.0 \\
\hline Remineralization rate & $\mathrm{d}^{-1}$ & 0.0035 \\
Sinking velocity & $\mathrm{m} \mathrm{d}^{-1}$ & 10.0 \\
Inorganic fraction & - & 0.08 \\
\hline Fe model parameters & & 0.1 \\
\hline Scavenging rate & $\mathrm{d}^{-1}$ & \\
Background & $\mu \mathrm{mol} \mathrm{Fe} \mathrm{m}^{-3}$ & \\
\hline
\end{tabular}

\subsection{Atmospheric carbon dioxide}

ACCESS-ESM1, mostly through capability inherited from the Met Office Unified Model, has the option of running with or without interactive $\mathrm{CO}_{2}$. When interactive $\mathrm{CO}_{2}$ is selected, a three-dimensional (3-D) atmospheric $\mathrm{CO}_{2}$ field is simulated and $\mathrm{CO}_{2}$ is transported through the atmosphere. This $\mathrm{CO}_{2}$ field influences the radiation calculation in the model as well as the calculation of the land and ocean carbon fluxes through CABLE and WOMBAT respectively. The atmospheric $\mathrm{CO}_{2}$ field is, in turn, dependent on the land and ocean carbon fluxes into or out of the atmosphere, along with any additional prescribed (e.g. anthropogenic) carbon flux. In this mode, ACCESS-ESM1 can simulate any climate-carbon feedback that might result from changing anthropogenic carbon fluxes. This mode is used for the CMIP5 emissionsdriven simulations. While maintaining an interactive 3-D $\mathrm{CO}_{2}$ field, an additional switch in ACCESS-ESM1, allows the model radiation scheme to revert to a prescribed (usually spatially constant) atmospheric $\mathrm{CO}_{2}$ mixing ratio. This en- ables simulations to be run that separate the direct effects of increasing atmospheric $\mathrm{CO}_{2}$ on simulated carbon fluxes from how the climate affects carbon fluxes.

When ACCESS-ESM1 is run without interactive $\mathrm{CO}_{2}$, the radiation scheme and carbon flux models are forced with a common prescribed atmospheric $\mathrm{CO}_{2}$ concentration. This might be constant in time for a pre-industrial control run, or increasing in time for historical or future scenarios. Many of the CMIP5 simulations run in this mode. When running in this way, we have also enabled the model to pass the land and ocean carbon fluxes into two of the passive tracer fields that are part of the Unified Model code. These tracers are transported through the atmosphere and allow us to assess the separate contributions of land and ocean carbon fluxes to features in observed atmospheric $\mathrm{CO}_{2}$ such as the seasonal cycle or interannual variability.

The atmospheric transport of $\mathrm{CO}_{2}$ does not perfectly conserve carbon. To ensure that carbon is conserved in the at- 
mosphere, a mass fixer has been applied as described in Sect. 2.2.2 of Jones et al. (2011).

\section{Model configuration}

The ACCESS-ESM1 atmosphere is run with a horizontal resolution of $1.875^{\circ}$ longitude $\times 1.25^{\circ}$ latitude, and with 38 vertical levels. The land surface has the same horizontal resolution but each grid cell comprises multiple tiles of different vegetation type. The ocean horizontal resolution is nominally $1^{\circ}$, with latitudinal refinements around the Equator $(0.33$ between $10^{\circ} \mathrm{S}$ and $10^{\circ} \mathrm{N}$ ) and the Southern Ocean (ranging from 0.25 at $78^{\circ} \mathrm{S}$ to $1^{\circ}$ at $30^{\circ} \mathrm{S}$ ), and a tripolar Arctic north of $65^{\circ} \mathrm{N}$ (Bi et al., 2013a). There are 50 ocean vertical levels with a nominal $10 \mathrm{~m}$ thickness in the upper ocean. In general the physical model configuration and forcings follow that used for the ACCESS1.3 CMIP5 simulations (Bi et al., 2013b; Dix et al., 2013), except that the ACCESS1.3 pre-industrial simulation did not include background stratospheric volcanic forcing. For ACCESS-ESM1, this forcing has been applied uniformly in time and space as an aerosol optical depth of 0.013 , the mean value of the stratospheric volcanic forcing applied from 1850 to 2000 in the ACCESSESM1 historical simulation. Atmospheric $\mathrm{CO}_{2}$ is prescribed at $285 \mathrm{ppm}$ throughout the pre-industrial simulation.

As noted above, CABLE can simulate land carbon fluxes with or without nutrient limitation. Here we have chosen to run CABLE in the "carbon, nitrogen and phosphorus (CNP)" configuration, based on results from some low-resolution ESM studies. Zhang et al. (2014) assessed the sensitivity of allowable emissions to nutrient limitation comparing cases running the carbon $(\mathrm{C})$ cycle alone, carbon and nitrogen $(\mathrm{CN})$ or CNP. Depending on the scenario and time period considered, the $\mathrm{CN}$ case reduced land carbon uptake by $35-40 \%$ relative to the $\mathrm{C}$ case, with a further $20-30 \%$ reduction in the CNP case. The CN and CNP cases were within the uncertainty range of estimated global land carbon uptake for the historical period, as compiled by Zhang et al. (2014). Zhang et al. (2013) assessed the interaction of land cover change with nutrient limitation. Again the CNP case gave land carbon uptake as more consistent with observations than the $\mathrm{C}$ only case.

For most of the work described here, two sets of simulations have been performed. In the first set, LAI is prescribed and there should be no interaction between the carbon cycle and the climate simulation (given that atmospheric $\mathrm{CO}_{2}$ is prescribed in these simulations). In the second set, LAI is prognostic and dependent on the size of the leaf carbon pool. In this case, the change in LAI has an impact on climate through its influence on radiation absorption and momentum, heat and moisture fluxes. The climate impact will be briefly examined in Sect. 4.1. The ocean carbon model configuration was the same for both the prescribed LAI and prognostic LAI simulations.

\subsection{Input files}

\subsubsection{Land}

Most of the input files and parameter settings (Supplement) for the biophysical component of CABLE were as described in Kowalczyk et al. (2013) including the LAI used in our prescribed LAI simulation. Note that the same LAI is used for all vegetation types within a grid cell.

Differences between the model configuration here and in Kowalczyk et al. (2013) are (a) a slight difference in the vegetation distribution used and (b) a change in the leaf optical property parameters. In total 13 surface types are differentiated: four forest types (evergreen needleleaf, evergreen broadleaf, deciduous needleleaf, deciduous broadleaf), six shrub and grass types (shrub, C3 grass, C4 grass, tundra, crop, wetland) and three non-vegetated types (lakes, ice, bare ground). As in Kowalczyk et al. (2013), the vegetation distribution is derived from Lawrence et al. (2012) but where Kowalczyk et al. (2013) restricted each grid cell to three dominant vegetation types; here vegetation types are selected based on whether they ever occur at greater than $10 \%$ of the grid cell at any time between 1850 and 2100 (under any CMIP5 historical or representative concentration pathway (RCP) scenario). This results in a variable number of vegetation types per grid cell, from one to seven. While the simulations presented here do not account for land use change and are all run with a pre-industrial (1850) vegetation distribution, the vegetation dataset has been constructed to allow further simulations in which the impacts of land use change are modelled. The vegetation distribution includes a small number of wetland tiles, but due to an incorrect setting for CASA-CNP, these were effectively excluded from the simulation of carbon fluxes. The small area involved means there is no significant impact on any simulation results presented here. The change in leaf optical properties (reflectance and transmission) for ACCESS-ESM1 was designed to be more consistent with the snow-free soil albedo used in ACCESS. The change was made to improve the low albedo simulated by ACCESS1.3 (Kowalczyk et al., 2013).

Additional input files are required for the biogeochemistry module of CABLE and these are based on Wang et al. (2010). Parameters (Supplement) such as the fraction of net primary production allocated to different pools and turnover times are specific to each vegetation type and are set from literature values or tuned based on offline simulations (Wang et al., 2010). We use the same prescribed leaf phenology as Wang et al. (2010), which gives the timing of green-up and leaf fall by latitude for all vegetation types except evergreen trees. We note here the limitation of using present-day leaf phenology for pre-industrial simulations and the inability of the model to simulate a changing growing season with changing climate. 
To simulate nitrogen and phosphorus requires nitrogen deposition and fixation, phosphorus from weathering and from dust and soil order, to distinguish soils of different mineralogy and age. These are all taken from Wang et al. (2010), re-gridded for the ACCESS-ESM1 model resolution and are representative of present-day conditions with no temporal variation. Nitrogen and phosphorus fertilizer is applied to all crop tiles at a present-day application rate taken from Wang et al. (2010). Given a smaller crop area in the 1850 vegetation distribution used in all simulations than for present-day, this gives a total fertilizer application that is a compromise between pre-industrial, present-day and future fertilizer use.

\subsubsection{Ocean}

The initial conditions for phosphate $(\mathrm{P})$ and oxygen $\left(\mathrm{O}_{2}\right)$ are derived from the 2005 version of the World Ocean Atlas (WOA2005; Garcia et al., 2006a, b). Phytoplankton in the top $100 \mathrm{~m}$ was initialized using chlorophyll (Chl $a$ ) taken from a climatology of SeaWIFS (1997-2008) and then scaled to phosphorus units using the ratio $\mathrm{P}: \mathrm{Chl} a=1 / 16 \mathrm{mmol} \mathrm{m}^{-3}$ $\mathrm{P}: 1.59 \mathrm{mg} \mathrm{m}^{-3} \mathrm{Chl} a$. Zooplankton was initialized as 0.05 of the initial phytoplankton concentrations. The initial field for iron $(\mathrm{Fe})$ was taken from a 500-year integration of a coarserresolution simulation of WOMBAT. Pre-industrial DIC and ALK are initialized from the Global Ocean Data Analysis Project (GLODAP; Key et al., 2004).

\subsection{Spin-up}

There was no formal spin-up of the carbon cycle before the ACCESS-ESM1 pre-industrial control run was started. The land carbon pools were initialized at values taken from repeated test simulations using the prognostic LAI configuration. The ocean BGC initial fields come from the observed climatology as described in the previous section. Offline land simulations and ocean-only simulations were explored to aid in the spin-up process but neither produced a satisfactory result at the time the pre-industrial run was started. This partly reflected the significant and evolving change of the mean climatology of the land, ocean and atmosphere from the present-day state.

\section{Results: pre-industrial control run}

In this section results from two ACCESS-ESM1 preindustrial control simulations will be characterized and compared. Each simulation presented here used prescribed (rather than interactive) atmospheric $\mathrm{CO}_{2}$ set to $285 \mathrm{ppm}$. The first simulation ran CABLE with prescribed leaf area index, which we denote "PresLAI" and the second simulation ran CABLE with prognostic LAI, denoted "ProgLAI". The ocean carbon configuration was the same for both simulations, using the ocean parameter set in Table 1. Both these simulations have been run for 1000 years .
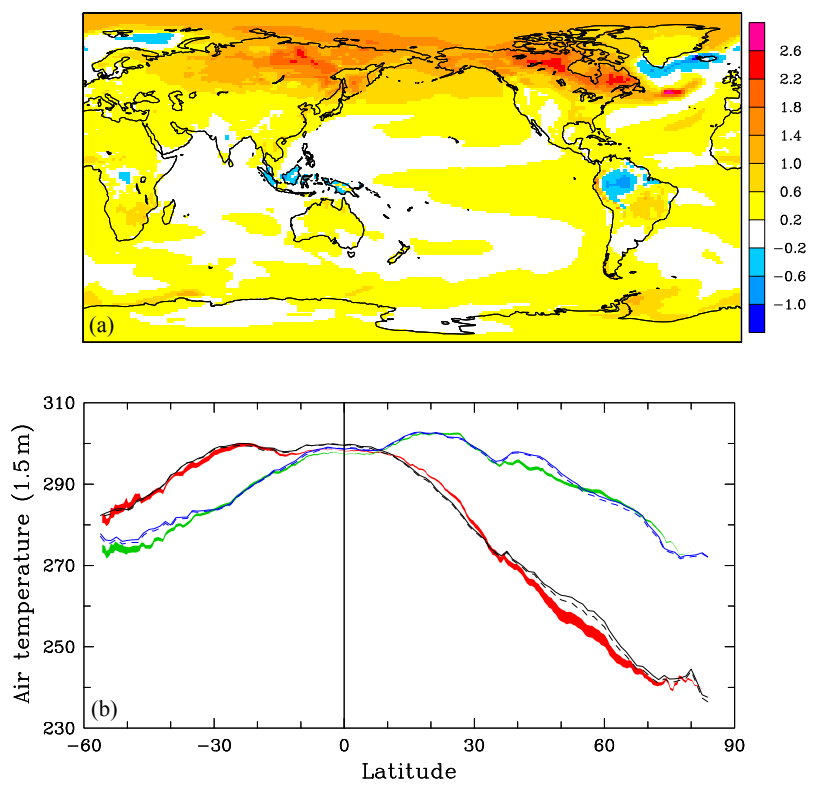

Figure 2. Surface air temperature difference (a) between ProgLAI and PresLAI for years 901-1000 and zonal mean land surface air temperature (b) for ProgLAI in January (black, solid) and July (blue, solid) and for PresLAI in January (black, dashed) and July (blue, dashed). The zonal mean \pm SD 1901-1910 observed land surface air temperature (Jones and Harris, 2014) is shown by the red shaded region for January and the green shaded region for July.

A brief analysis of the simulated climate is presented first (Sect. 4.1), focussing on how the climate simulation is impacted in the ProgLAI case and on climate variables most relevant to the carbon cycle simulation. Analysis of the equilibration of land and ocean carbon fluxes follows (Sect. 4.2). Spatial distributions of fluxes are presented with the focus for land carbon being on the sensitivity to the simulation of LAI (Sect. 4.3). For ocean carbon, we focus on the sensitivity to the ocean circulation simulation by comparing the ACCESS-ESM1 results with those from an ocean-only simulation (Sect. 4.4). Finally, we assess the interannual variability of the carbon fluxes (Sect. 4.5). Understanding the sensitivity of carbon fluxes to natural climate variability may be useful for interpreting the response of carbon fluxes to externally forced climate change, as well as for model evaluation.

\subsection{Climate}

In general, the pre-industrial climate simulations for both configurations of ACCESS-ESM1 are very similar to that of ACCESS1.3 (Bi et al., 2013b) and ACCESS1.4 (Appendix A). Running ACCESS-ESM1 with prognostic LAI results in globally warmer surface air temperature $(14.59 \pm$ $0.11^{\circ} \mathrm{C}$ averaged over the final 300 years of the ProgLAI simulation compared to $14.22 \pm 0.10^{\circ} \mathrm{C}$ for the PresLAI case). The surface warming extends through the troposphere and is largest over northern high-latitude continents (typi- 
cally $1-2{ }^{\circ} \mathrm{C}$ ) while over tropical forests the ProgLAI case is slightly cooler (around $0.5^{\circ} \mathrm{C}$ ) than the PresLAI case (Fig. 2a). The northern high-latitude warming is more pronounced in winter than summer suggesting an interaction between LAI and snow. For example, larger LAI would mean less snow visible under the leaf canopy, a reduced albedo and a consequent higher temperature. The simulated prognostic LAI is presented in Sect. 4.3; lower prognostic than prescribed LAI generally appears to result in lower temperatures and vice versa, at least where the LAI changes are relatively small. A much reduced LAI appears to be associated with warming in some parts of the tropics. The different temperature impacts show that there is no simple relationship between LAI and temperature, rather LAI impacts on many components of the surface energy balance. We also note that the temperature differences triggered by changes in LAI are small compared to the tropical-polar temperature gradient and seasonal cycles of temperature (Fig. 2b) and both simulations give temperature distributions that are close to those derived from observations (Jones and Harris, 2014).

The ACCESS-ESM1 simulations of precipitation are similar to ACCESS1.3 and ACCESS1.4 (Appendix A). This means that precipitation biases identified in ACCESS1.3 (Kowalczyk et al., 2013) are also present in ACCESS-ESM1, in particular negative precipitation biases over India in JuneAugust and over the Amazon in December-February (their Fig. 9). These biases have implications for the sustainability of vegetation due to insufficient moisture (Sect. 4.2.1) with consequent impacts on the simulation of the land carbon cycle.

To provide a perspective on the ocean dynamics of ACCESS-ESM1, we show the global meridional overturning stream function, the annual maximum mixed layer depth and sea-ice area for the last 100 years of the simulation. For these ocean diagnostics, the two ACCESS-ESM1 simulations are very similar, and we only show the results from the simulation with prognostic LAI.

Global meridional overturning circulation from ACCESSESM1 (Fig. 3a) shows a maximum strength in the Antarctic Bottom Water cell of $8 \mathrm{~Sv}$, which is comparable to previous ACCESS simulations (Bi et al., 2013a). The maximum strength of the North Atlantic Deep Water cell is about $24 \mathrm{~Sv}$, which is also comparable to other CMIP5 simulations.

The maximum mixed layer depth of ACCESS-ESM1 shows maximum mixed layers deeper than $1000 \mathrm{~m}$ in the Ross and Weddell seas and the North Atlantic (Fig. 3b). The Sub-Antarctic Zone is also a region where maximum mixed layer depths show regional maxima with mixed layer depths approaching $600 \mathrm{~m}$, which is comparable to observations. Both the spatial pattern and magnitude of the maximum annual mixed layer depths in the ACCESS-ESM1 simulation are comparable to previous ACCESS1.3 and 1.4 simulations (Marsland et al., 2013; Uotila et al., 2013).

To assess the ACCESS-ESM1 simulation of sea ice, we show the seasonal climatology of the northern and south-
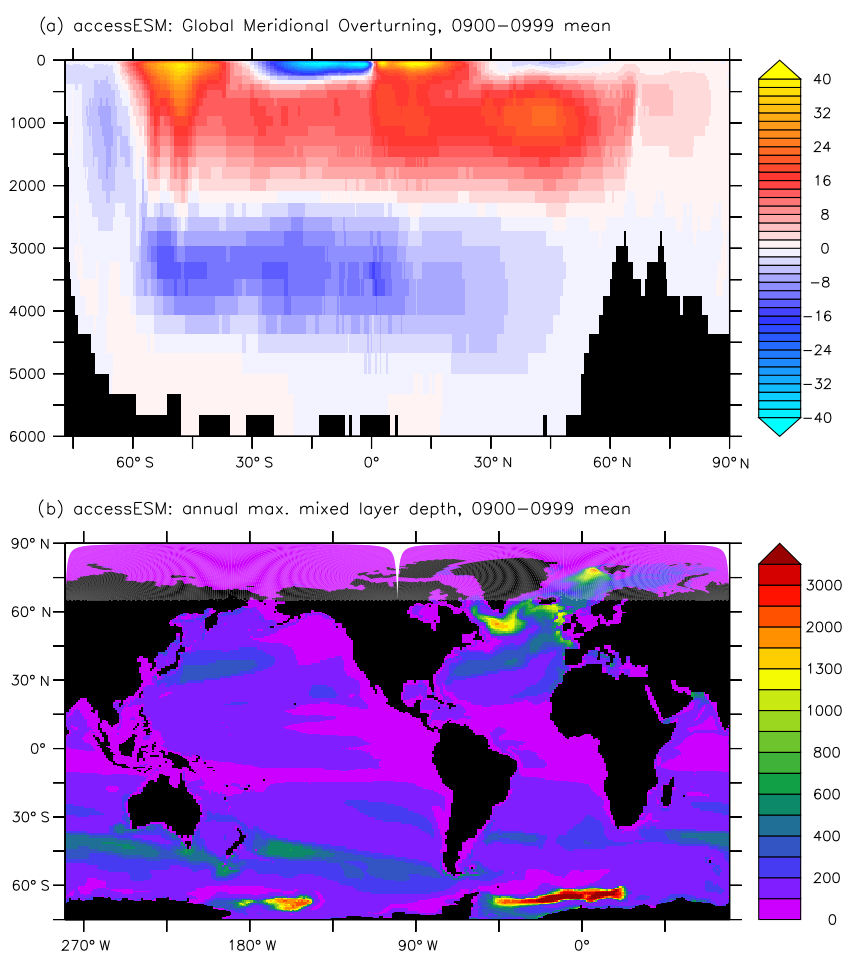

Figure 3. ACCESS-ESM1 from the last 100-year average of the pre-industrial simulation for (a) global meridional overturning stream function $(\mathrm{Sv})$ and (b) maximum annual mixed layer depth (m).

ern sea-ice area from the last 100 years of the simulation (Fig. 4a). In both hemispheres the seasonal climatology is similar to the observations but with a tendency to slightly underestimate the sea-ice area. Such behaviour is similar to other ACCESS simulations and other CMIP5 simulations (Marsland et al., 2013; Uotila et al., 2013). The simulated annual average sea-ice area for ACCESS-ESM1 is similar to the observed values of $11.6 \pm 0.6 \times 10^{12}$ and $11.6 \pm 0.5 \times$ $10^{12} \mathrm{~m}^{2}$ for the Northern and Southern hemispheres respectively (Comiso, 2000). The simulation shows much greater variability in the annual average in the Southern Hemisphere than the Northern Hemisphere (Fig. 4b).

\subsection{Carbon equilibration}

The temporal evolution of the global net NEE and sea-air carbon flux over the 1000 years of simulation is shown in Fig. 5, with the expectation that the fluxes should equilibrate to zero. The two simulations give very similar results for the sea-air flux, consistent with the use of the same ocean carbon configuration and initial conditions. The flux is slowly approaching zero, reaching around $0.6 \mathrm{PgC} \mathrm{yr}^{-1}$ after 1000 years. Missing values in the sea-air flux are due to a numerical instability, which manifests as a very large sea-air flux in the North Atlantic that decays over a few years. A reformulation of the ocean carbon code resolved 
(a)

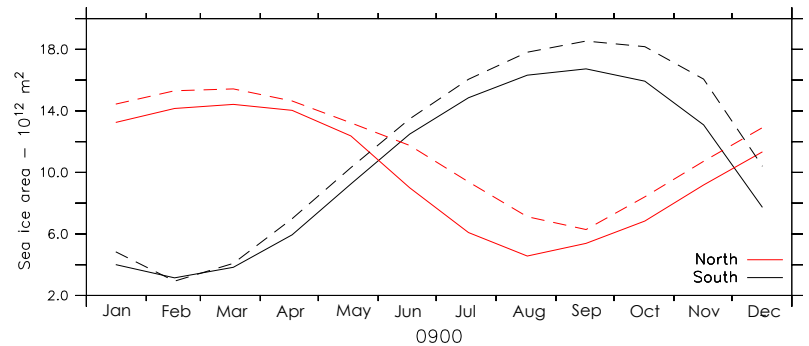

(b)

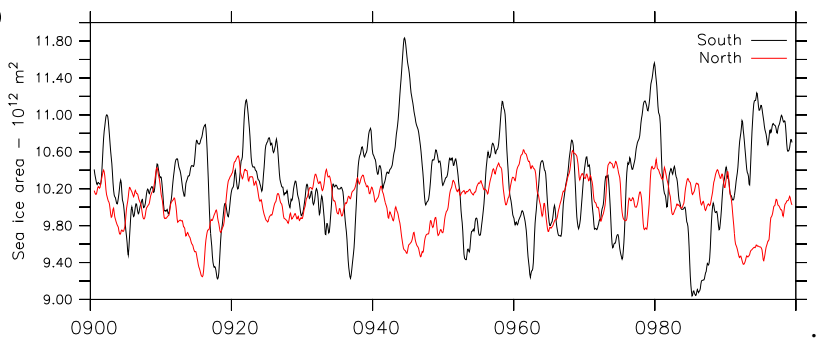

Figure 4. ACCESS-ESM1 simulated (solid) sea-ice are for the Northern (red) and Southern (black) hemispheres from the last 100 years of the pre-industrial simulation for (a) seasonal climatology and (b) annual mean area. Observed seasonal sea-ice area (dashed) is based on Comiso (2000)

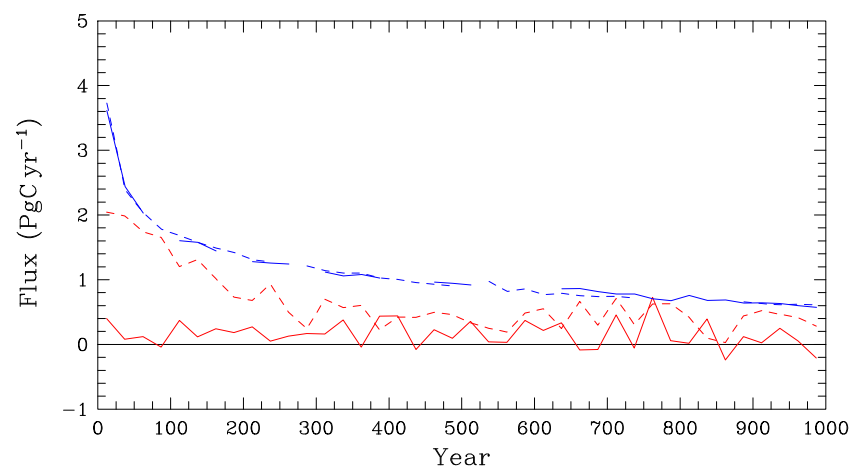

Figure 5. The 25-year mean global sea-air carbon flux (blue) and NEE (red) in $\mathrm{PgC}_{\mathrm{yr}}{ }^{-1}$ for the ProgLAI simulation (dashed) and the PresLAI simulation (solid). Ocean fluxes are missing where they are impacted by a numerical instability (see text).

this and was implemented towards the end of the simulations (and subsequent historical and future scenarios). The evolution of the land carbon flux differs across the two simulations because the prognostic LAI configuration had been run for several hundred years in test runs before the start of the 1000-year simulation while the PresLAI case had not. Hence, the ProgLAI case is close to zero throughout the simulation, whereas in the PresLAI case, respiration is larger than GPP giving a net source to the atmosphere that decreases from around $2 \mathrm{PgCyr}^{-1}$. The equilibration of the fluxes is explored further, first for land carbon and second for ocean carbon.

\subsubsection{Land carbon equilibration}

In both land carbon configurations, total respiration remains slightly larger than GPP and NEE does not quite equilibrate to zero; over the last 500 years of the simulation the global NEE is $0.40 \mathrm{PgC} \mathrm{yr}^{-1}$ for PresLAI and $0.14 \mathrm{PgCyr}^{-1}$ for ProgLAI. Figure 6 shows, for the ProgLAI case, the vegetation types that are slowest to equilibrate, along with the carbon and nutrient pools that are still changing at the end of the simulation. The evergreen broadleaf and deciduous broadleaf vegetation types make the largest contribution to the non-zero NEE (Fig. 6a), and a similar result is found for PresLAI (not shown). The tundra vegetation type gives negative NEE, getting closer to zero over time. This vegetation type was found to be particularly susceptible to a poor initial choice of pool sizes, which impeded the spin-up to equilibrium due to excessive loss of soil nutrients, particularly phosphorus. Tundra pools are still recovering in the first 500 years of this simulation. Evergreen needleleaf vegetation shows little trend in NEE but some variability between 100-year periods. Other vegetation types (not shown) are generally close to zero NEE after the first 100 years .

The slightly positive NEE flux to the atmosphere should be balanced by a decrease in the total carbon across all pools (Fig. 6b). The decrease is dominated by carbon loss from the passive soil pool (which has the longest turnover time). The slow soil pool and plant wood pool show much smaller differences over time, being a carbon gain and a carbon loss respectively. The figure shows centennial-scale variability in these pools, which contributes to the decadal to centennialscale variability seen in the total carbon and likely explains the small gain in total carbon over the last 150 years of the simulation. Around two-thirds of the carbon loss in the passive soil pool can be attributed to evergreen broadleaf tiles, consistent with this type contributing the largest non-zero NEE at the end of the simulation.

The behaviour of the nitrogen pools (Fig. 6c) is broadly similar to the carbon pools with nitrogen loss from the passive soil pool, again largely from the evergreen broadleaf vegetation type. This loss is offset, to a greater extent than for carbon, by increases in nitrogen in the slow soil pool, primarily for the tundra vegetation type. The trend in pools is a little different for phosphorus (Fig. 6d) with both the passive and slow soil pools growing, while the inorganic phosphorus pools are declining. The pools that are changing most are typically those with the longest residence times. As for nitrogen the slow soil pool change is dominated by the tundra vegetation type but the other pool changes are split more evenly across a range of vegetation types.

Over the last 500 years of the simulations the total carbon pool decreases by $0.09 \mathrm{PgCyr}^{-1}$ for PresLAI and $0.06 \mathrm{Pg} \mathrm{Cyr}^{-1}$ for ProgLAI. These differences are substantially smaller than the NEE over this period $(0.40$ and $0.14 \mathrm{PgC}^{-1}$ respectively) indicating a problem with land carbon conservation. Analysis across all vegetated tiles 

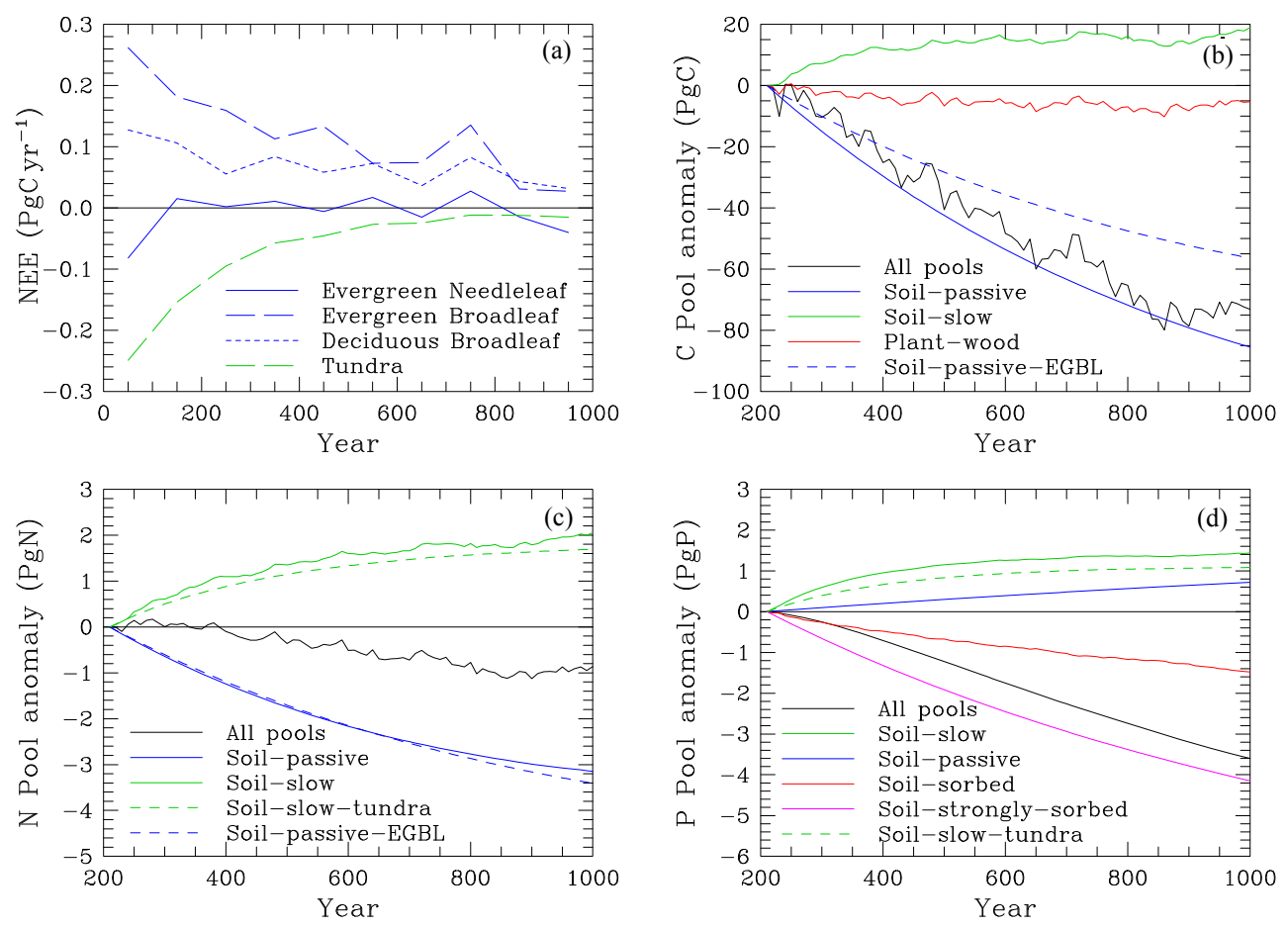

Figure 6. The 100-year mean global NEE (a) in $\mathrm{PgC} \mathrm{yr}^{-1}$ for selected vegetation types as listed in the key and carbon (b), nitrogen (c) and phosphorus (d) pool sizes in $\mathrm{Pg} \mathrm{C}, \mathrm{Pg} \mathrm{N}$ and PgP at the end of each 10 years relative to year 210 for the sum of all pools (black), and selected pools (as listed in the key - solid: pools summed over vegetation type; dashed: pools for listed vegetation type; EGBL is evergreen broadleaf) for the ProgLAI simulation. The horizontal black line indicates zero NEE (a) and zero pool anomaly (b-d).

shows that poor carbon conservation occurs when rainfall is low, the soil column dries out and the leaf carbon pool is fully depleted. In these circumstances, fluxes become small but inconsistent, in part due to CABLE maintaining a minimum LAI even when no leaf carbon is present. Resolving this inconsistent behaviour in CABLE is a high priority but has proved challenging. Overall around $15 \%$ of tiles are impacted to some extent, but the largest NEE imbalances are confined to relatively small regions in India and eastern tropical South America (Fig. S1 in the Supplement), which are known to have negative rainfall biases (Kowalczyk et al., 2013). Given the land carbon calculation in each tile is independent, a lack of conservation in individual tiles does not adversely impact any other tiles and very little impact is seen on the overall characteristics of the model simulation.

\subsubsection{Ocean carbon equilibration}

By design WOMBAT conserves the biogeochemical tracers in the ocean, which means the rate of change in the total carbon in the ocean and sediment pools equals the net sea-air flux. The temporal evolution of the global sea-air flux of carbon for the last 100 years of the simulation is shown in Fig. 7a. By the end of the simulation, the net outgassing of carbon from the ocean is about $0.55 \mathrm{PgC} \mathrm{yr}^{-1}$. The net seaair flux is declining but will take several thousands of years to reach zero. For comparison, Séférian et al. (2016) showed the drift in one CMIP5 model (their Fig. 2) where the magnitude of the modelled sea-air imbalance is similar to our simulation $\left(0.6 \mathrm{PgC} \mathrm{yr}^{-1}\right)$.

As the carbon equilibration time is set by the millennium timescale of deep water circulation, existing computational resources are insufficient to allow the ESM simulation to reach full carbon equilibrium ( $\sim 4000$ years $)$. We explored using the ocean initial state from a long simulation of an ocean-only simulation driven by climatological atmospheric re-analysis fields. This failed to reduce the drift because the climate of ACCESS-ESM1 was substantially different from the atmospheric re-analysis fields and hence the ocean circulation differed significantly from the ocean-only simulation.

Within WOMBAT, if particulate organic matter and calcium carbonate are not remineralized before reaching the seafloor they can accumulate in the sediments. We implemented this simple sediment pool to handle high flux events and reduce the possibility of numerical instabilities. The ESM simulation showed that the global organic and inorganic carbon in the sediments are stable and small (Fig. 7b) compared to the total amount of carbon dissolved in seawater $(\approx 37000 \mathrm{Pg}$ C; Ciais et al., 2013). Therefore, in the ESM simulation the net sea-air flux of carbon equals the total change in carbon dissolved in the ocean. 

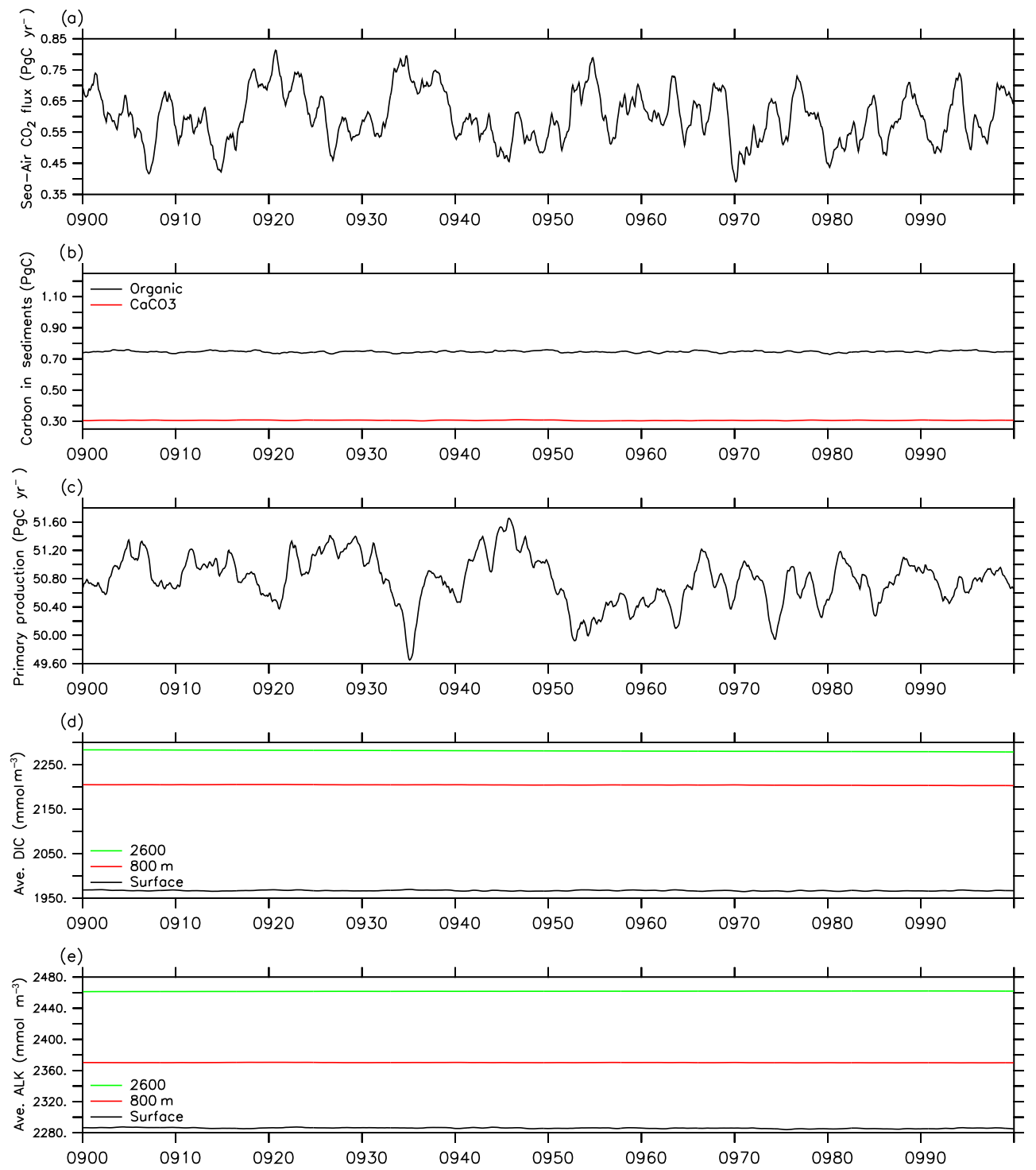

Figure 7. For the ACCESS-ESM1 simulation the global (a) sea-air flux of carbon dioxide in $\mathrm{PgC}^{-1}{ }^{-1}$, (b) carbon content of the organic (black) and calcium carbon sediment (red) pools in $\mathrm{PgC}$, (c) net primary productivity in $\mathrm{PgC}^{-1}$, (d) global-averaged dissolved inorganic carbon in $\mathrm{mmol} \mathrm{m}^{-3}$ at various depths and (e) global average alkalinity in $\mathrm{mmol} \mathrm{m}^{-3}$ at various depths.

While there is a slow decline in the global mean sea-air carbon flux, the upper ocean dynamics have largely stabilized as shown by no trend in the simulated annual mean primary productivity (Fig. 7c) and no discernable trends in global surface DIC and alkalinity concentrations (Fig. $7 \mathrm{~d}$ and e). Over the last 100 years of the simulation the annual mean primary productivity is about $51 \pm 1 \mathrm{PgC} \mathrm{yr}^{-1}$. The value is consistent with global estimates of primary productivity, which range between 45 and $50 \mathrm{Pg} \mathrm{Cyr}^{-1}$ (e.g. Carr et al., 2006).

\subsection{Land carbon sensitivity to LAI}

Land carbon cycle fluxes are characterized by their spatial and seasonal distributions and their sensitivity to LAI. Fig. 8a compares the simulated LAI for all vegetation types in the ProgLAI simulation with that used in the prescribed (PresLAI) case. In the prescribed LAI case, the same LAI is used for all tiles within a grid cell regardless of vegetation type, varying seasonally but not from year to year. Zonally averaged, the prescribed LAI is largest in the tropics, peaking at over 3.0, with annual values closer to 1.0 in the mid-latitudes. In ProgLAI, the simulated LAI values are lower in the tropics than those prescribed for all vegetation types. This contrasts with the simulated LAI in the mid-latitudes when all vegetation types show as large or much larger values than those prescribed. In general the evergreen tree types show larger LAI than the other vegetation types. This is likely more significant for the evergreen needleleaf type due to its relatively 


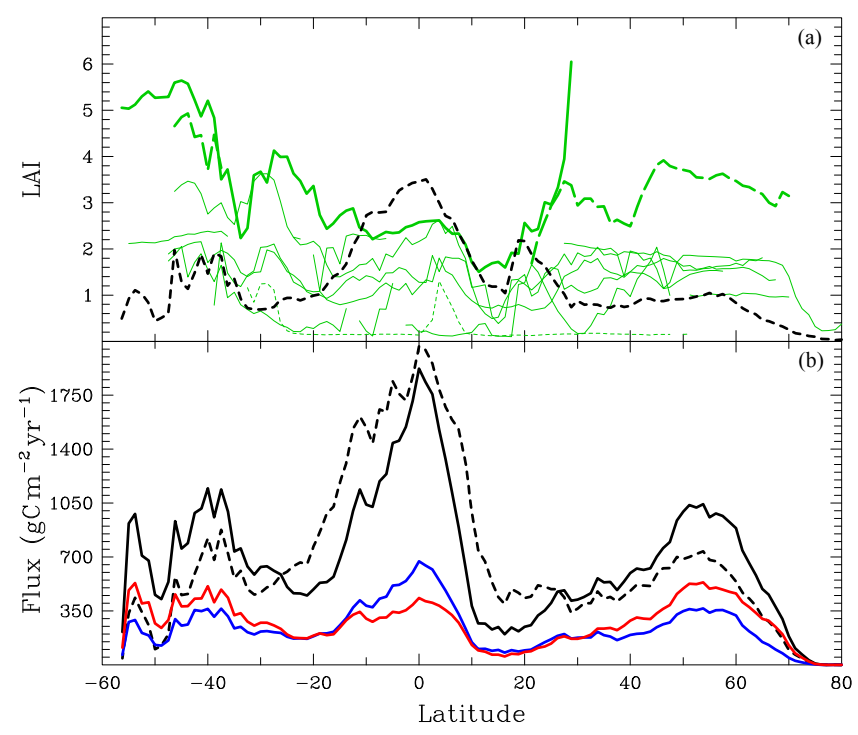

Figure 8. Zonal mean year 501-1000 leaf area index (a) and carbon flux (b) in $\mathrm{g} \mathrm{C} \mathrm{m}^{-2} \mathrm{yr}^{-1}$. For ProgLAI, the LAI is zonally averaged over all tiles for each vegetation type separately (evergreen broadleaf trees, bold green; evergreen needleleaf trees, bold dashed green; C4 grass, dotted green; all other types, solid green). For PresLAI, the LAI is zonally averaged over all land grid cells (black, dash). Carbon fluxes are zonally averaged over all land grid cells, showing from ProgLAI, GPP (black solid), plant respiration (blue) and soil respiration (red) and from PresLAI, GPP (black, dashed).

large areal extent in the northern mid-latitudes, whereas the very large simulated LAI values for the evergreen broadleaf type are limited to a very small number of tiles. C4 grass is particularly low over much of its geographical range. It appears that $\mathrm{C} 4$ grass is more sensitive to low rainfall than colocated $\mathrm{C} 3$ grass, especially when CABLE is run with prognostic $v_{\text {cmax }}$. While $\mathrm{C} 4$ vegetation is annual and expected to dieback under dry conditions, CABLE does not appear capable of re-growing the vegetation when rainfall does occur. Some improvement in the simulation might be achieved through parameter tuning, but revision of the model formulation for $\mathrm{C} 4$ plants may also be required.

The differences in prescribed and simulated LAI are reflected in the zonal mean GPP over the last 500 years (Fig. 8b). In both cases the GPP distribution gives maximum GPP in the tropics but the PresLAI is larger, consistent with the larger LAI. ProgLAI gives relatively higher GPP in the mid-latitudes $\left(40-60^{\circ}\right)$. Globally GPP is slightly larger for the PresLAI run at $116.4 \mathrm{PgCyr}^{-1}$ compared to 110.2 $\mathrm{Pg} \mathrm{Cyr}^{-1}$ for the ProgLAI case. Zonal mean respiration is shown for the ProgLAI case only (Fig. 8b). Plant respiration generally exceeds soil respiration in the tropics but tends to be smaller than soil respiration at mid-high latitudes.

Land carbon fluxes are highly seasonal and this is captured by the model; Fig. 9 shows NEE for the final 100 years of the simulation. In the extra-tropics NEE is positive in winter

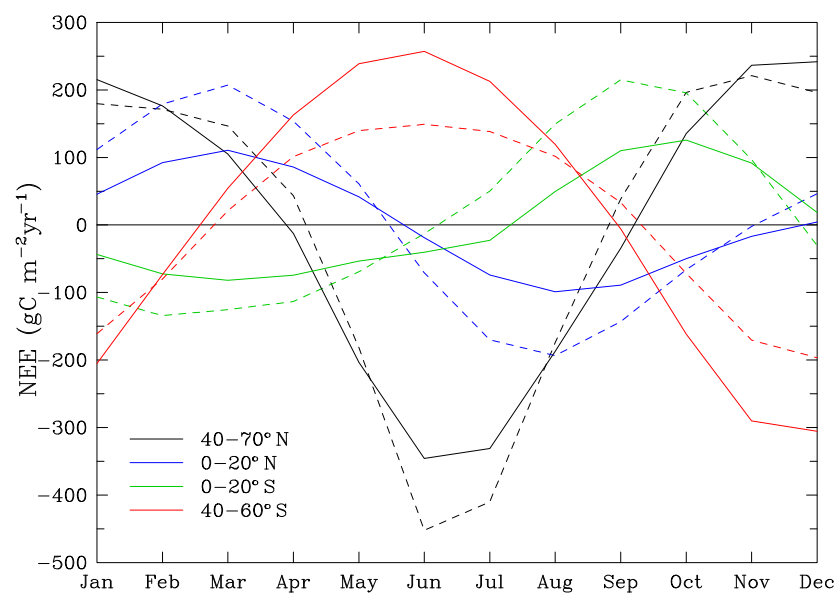

Figure 9. Monthly mean NEE in $\mathrm{gC}^{-2} \mathrm{yr}^{-1}$ for years $901-1000$ averaged over the land grid cells in four latitude bands (as listed in the key), for PresLAI (dashed) and ProgLAI (solid).

and negative in summer (driven by available radiation), while in the tropics the NEE seasonality follows precipitation, with carbon uptake in the wet season and release in the dry season. With the exception of the southern extra-tropics, the NEE seasonality is smaller in magnitude for the ProgLAI case than for the PresLAI case. In the northern extra-tropics ProgLAI shows a longer growing season but with less uptake in June and July, while positive fluxes in winter are similar to the PresLAI case. In the tropics both carbon uptake and release are smaller for ProgLAI, reflecting the lower-simulated LAI in the tropics. In the southern extra-tropics, the larger NEE seasonality in ProgLAI will not have a large impact on the total carbon flux to the atmosphere since the southern extratropical land area is very small.

Further assessment of the land carbon flux and pool distribution is presented in Ziehn et al. (2017) using the ACCESSESM1 historical simulation and comparing with observations.

\subsection{Ocean carbon sensitivity to ocean circulation}

The ocean carbon cycle simulation is characterized by comparing the spatial distribution of key BGC fields with observations. We first look at the ACCESS-ESM1 simulation of net primary productivity (NPP), surface phosphate, export production from $100 \mathrm{~m}$ and sea-air $\mathrm{CO}_{2}$ fluxes from the last 100 years of the simulation (Fig. 10). In this comparison, we have also included the ACCESS ocean-only simulation forced by the CORE seasonal mean forcing (Large and Yeager, 2004), with the same ocean carbon parameters as ACCESS-ESM1, to evaluate how biases in the climate model impact the ocean carbon cycle. The observed estimates of NPP are based on using the chlorophyll derived from the seasonal SeaWiFS climatology and the Eppley-VGPM algorithm. The algorithm employs the basic model structure 
(a)
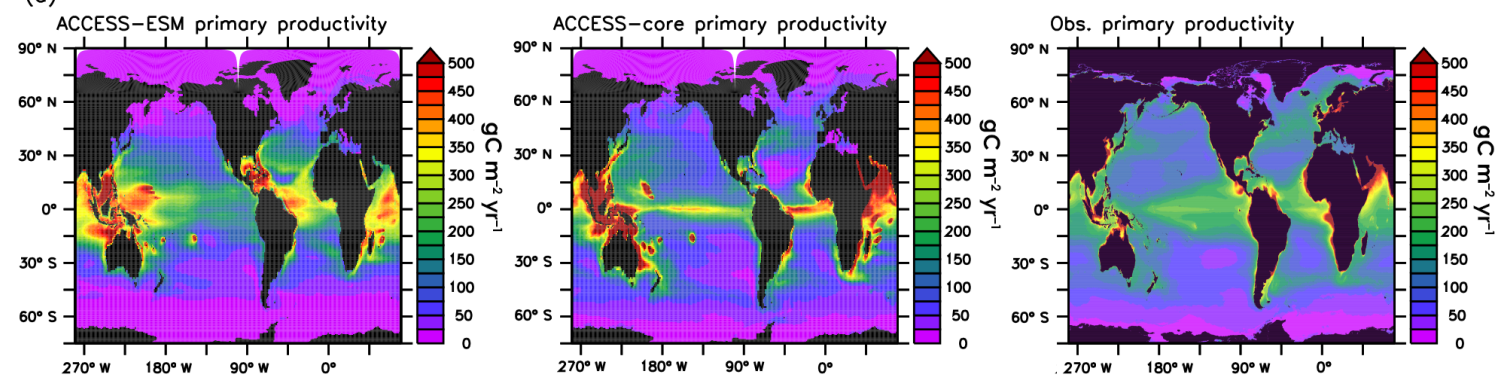

(b) ACCESS-ESM export prod.
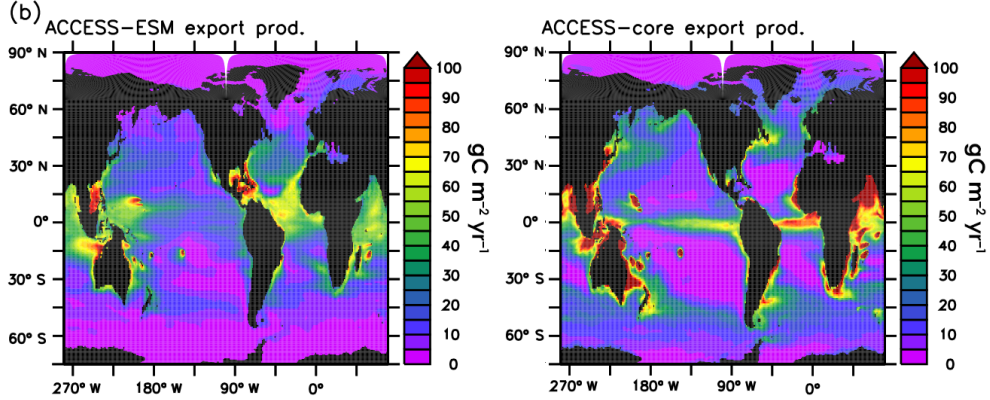

(c) ACCESS-ESM surface Pho
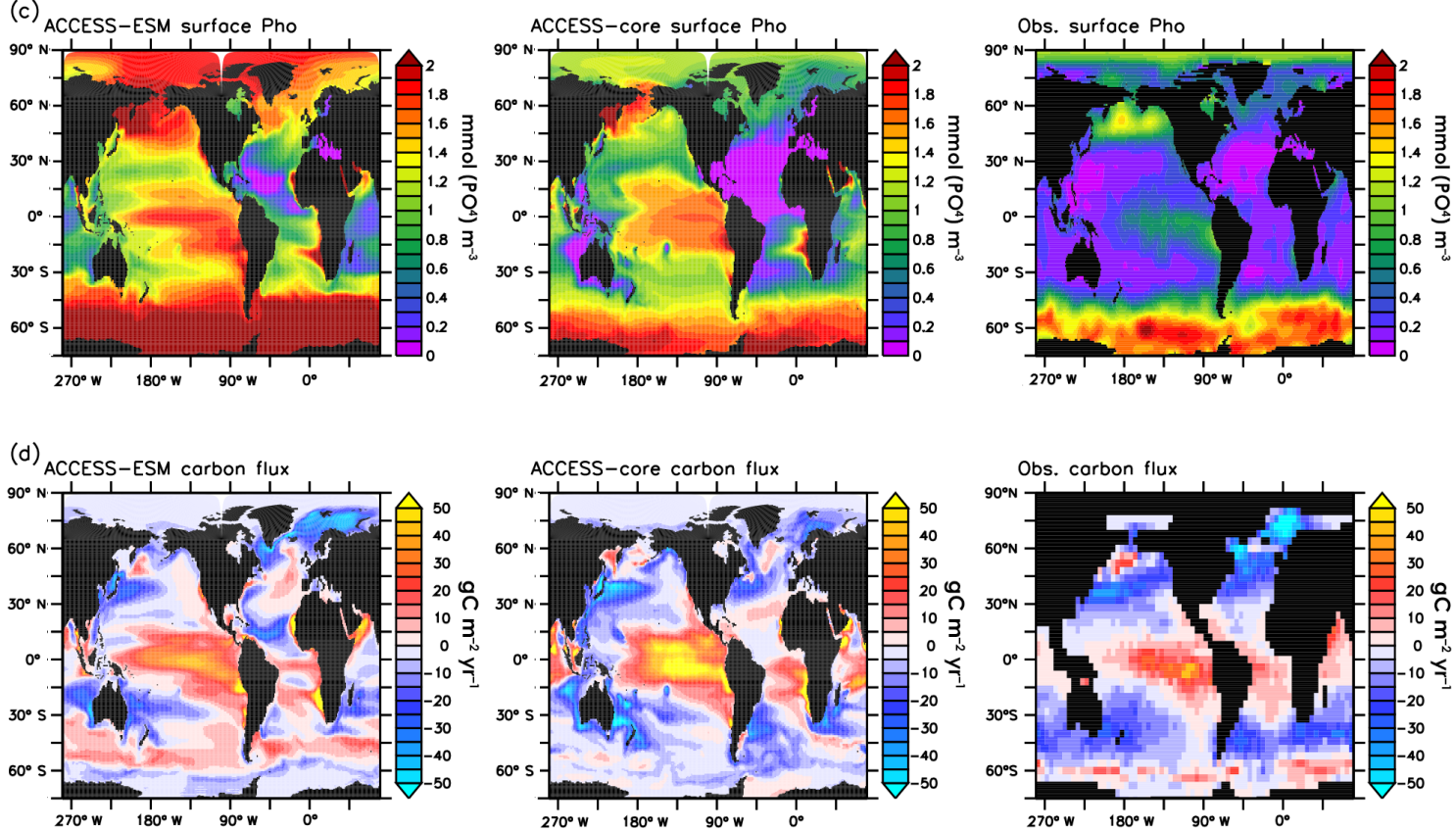

Figure 10. Comparison of the ACCESS-ESM1 simulation (left column) for the years 901-1000 with an ocean-only simulation (middle col-

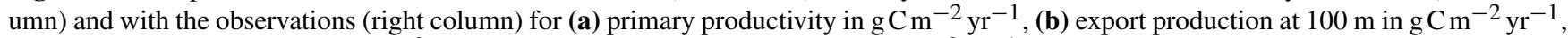
(c) surface phosphate in mmolPm${ }^{-3}$ and (d) mean sea-air flux of $\mathrm{CO}_{2}$ in $\mathrm{g} \mathrm{Cm}^{-2} \mathrm{yr}^{-1}$. Observed primary productivity is based on the Eppley-VGPM algorithm. The surface phosphate observations come from the World Ocean Atlas climatology (WOA2005; Garcia et al., 2006a). The annual sea-air $\mathrm{CO}_{2}$ fluxes are from Takahashi et al. (2009).

and parameterization of the standard VGPM (Behrenfeld and Falkowski, 1997) but replaces the polynomial description of $\mathrm{Pb}_{\text {opt }}$ with the exponential relationship described by Morel (1991) and based on the curvature of the temperaturedependent growth function described by Eppley (1972). The observations for phosphate come from the World Ocean Atlas climatology (WOA2005; Garcia et al., 2006a). The annual sea-air fluxes of $\mathrm{CO}_{2}$ are based on Takahashi et al. (2009). 
The ACCESS-ESM1 simulation of NPP is poor with too much production in the western tropical Indian and $\mathrm{Pa}$ cific oceans and too little NPP in the high-latitude oceans (Fig. 10a). The excessive NPP in the tropics and underestimated NPP in the high latitudes is exacerbated in the ACCESS-ESM1 simulation compared to the ocean-only simulation, revealing that biases in the climate simulation significantly degrade NPP. The excessive tropical Pacific NPP reflects the strong cold tongue bias in the ACCESS-ESM1 simulation, which upwells too much phosphate in the tropical Pacific and elevates phosphate in the western tropical Pacific particularly. Outside of the tropics NPP from the ocean-only simulation is generally slightly less than the observations and NPP further declines in the ESM simulation. Changes in NPP between the ESM simulation and the ocean-only simulation reflect biases in the circulation and enhanced recycling of phosphate in the upper ocean. The enhanced recycling of phosphate in the ACCESS-ESM1 simulations is revealed by greater tropical NPP but less export production through $100 \mathrm{~m}$ (Fig. 10b). The enhanced recycling of nutrients further helps to increase the phosphate concentration in the surface and to degrade the phosphate simulation (Fig. 10c).

NPP shows much greater difference between the ESM and ocean-only simulation than net sea-air flux (Fig. 10d). The similarity suggests the sea-air fluxes are not too sensitive to the NPP biases of the ESM simulation because most of the changes in the ESM simulation reflected increased nutrient recycling rather than increased carbon export out of the upper ocean. The sea-air carbon flux for the last century of the ESM simulation (901-1000) shows outgassing in the tropical ocean and in the Southern Ocean and uptake in the Southern and Northern hemispheres mid-latitudes. This spatial pattern of the sea-air fluxes is in agreement with the integrated pre-industrial zonal sea-air fluxes estimated by Gruber et al. (2009) and similar to the present-day flux climatology of Takahashi et al. (2009), which includes the anthropogenic increase in atmospheric $\mathrm{CO}_{2}$.

Zonally averaged sections of phosphate, oxygen, DIC and alkalinity concentrations are compared to observations to help further assess the ACCESS-ESM1 simulation (Fig. 11). Again, the ocean-only (CORE forcing) simulation is also shown. The observations for phosphate come from the World Ocean Atlas climatology (WOA2005; Garcia et al., 2006a), while pre-industrial DIC and alkalinity are from GLODAP (Key et al., 2004).

The ACCESS-ESM1-simulated DIC values are too low throughout the ocean, in part because the low surface alkalinity lowers $p \mathrm{CO}_{2}$ in the surface and retards the solubility uptake of $\mathrm{CO}_{2}$ (Fig. 11a). For alkalinity, the simulated values are too low at the surface with a too strong vertical gradient (Fig. 11b). The ocean-only simulations give broadly similar results. Reducing the export of calcium carbonate would help improve the simulated alkalinity by raising surface alkalinity and reducing alkalinity in the ocean interior.
The phosphate section shows the simulated deep water concentrations are slightly less than observed with a big positive bias in the simulation confined to the upper $1000 \mathrm{~m}$ of the ocean (Fig. 11c). The bias is smaller in the ocean-only simulation. Deepening the remineralization of sinking detritus would be one way to transfer the excessive phosphate from the upper ocean into the deep ocean. The deepening of detritus remineralization would help reduce the simulated excessive oxygen concentrations and raise the DIC concentrations in the deep ocean and make the simulation more consistent with the observations (Fig. 11a and d).

While more effort is required to tune the ocean BGC parameters to increase the depth of detritus remineralization and reduce calcium carbonate export, Ziehn et al. (2017) will show that the ACCESS-ESM1 overall behaviour of the surface BGC fields is not significantly worse than other CMIP5 simulations. However, the biases in the ACCESS-ESM1 simulation will need to be considered when interpreting how the model responds to historical and future atmospheric $\mathrm{CO}_{2}$ levels. The biases in the ocean BGC fields, which are apparent in the ocean-only simulation, are exacerbated in the ESM simulations. Therefore, to produce realistic BGC fields in the ESM simulation one cannot rely on the ocean-only simulation for tuning the BGC parameters and additional tuning must be done with the ESM.

\subsection{Interannual variability}

The pre-industrial simulation is useful for exploring the natural variability in carbon fluxes and the relationship of this variability to variability in climate. The interannual variability of carbon flux to the atmosphere is much larger for the flux from the land than from the ocean (Fig. 12a and b). Maximum variability for the ocean flux is found in the tropics and high northern latitudes. Maximum variability for the land flux is at least an order of magnitude larger than for the ocean and is focussed in the tropics for the PresLAI case and also in the mid-latitudes in the ProgLAI case. Although the variability of global NEE is slightly larger for the PresLAI case than the ProgLAI case (Table 2), the standard deviation of annual GPP in the ProgLAI case is $60 \%$ larger than in the PresLAI case. Variability in the respiration fluxes is also larger for ProgLAI, particularly for the leaf respiration. The slightly smaller standard deviation for the ProgLAI global NEE is because GPP and leaf respiration are strongly positively correlated in the ProgLAI case, driven by the interannual variations in LAI. In the PresLAI case, with fixed LAI from year to year, the relatively small interannual variability in leaf respiration appears to be most strongly driven by temperature and has a moderate negative correlation with interannual variations in GPP.

Figure $12 \mathrm{c}$ and $\mathrm{d}$ also show the autocorrelation of carbon flux to the atmosphere for 1-year lag. This shows mostly positive correlations for the ocean flux and for the ProgLAI land flux but little 1-year autocorrelation for land in the Pres- 
(a)

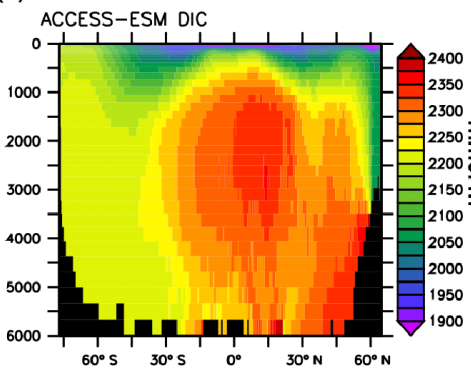

(b) ACCESS-ESM alkalinity

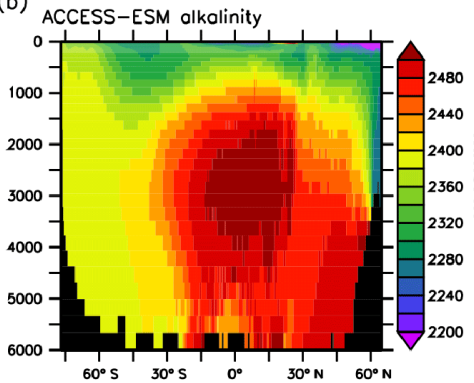

(c)

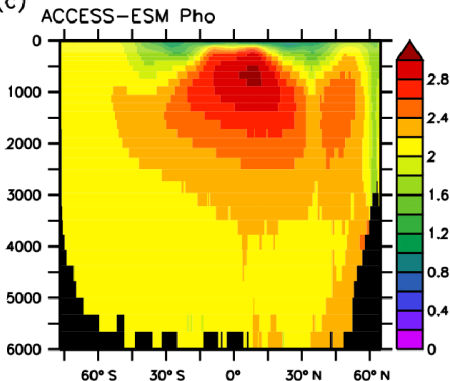

(d)

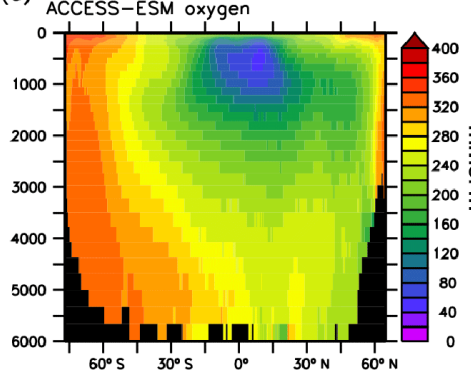

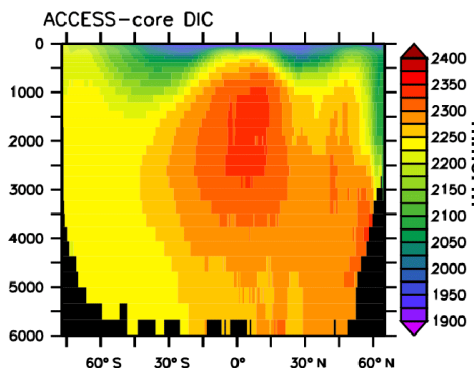
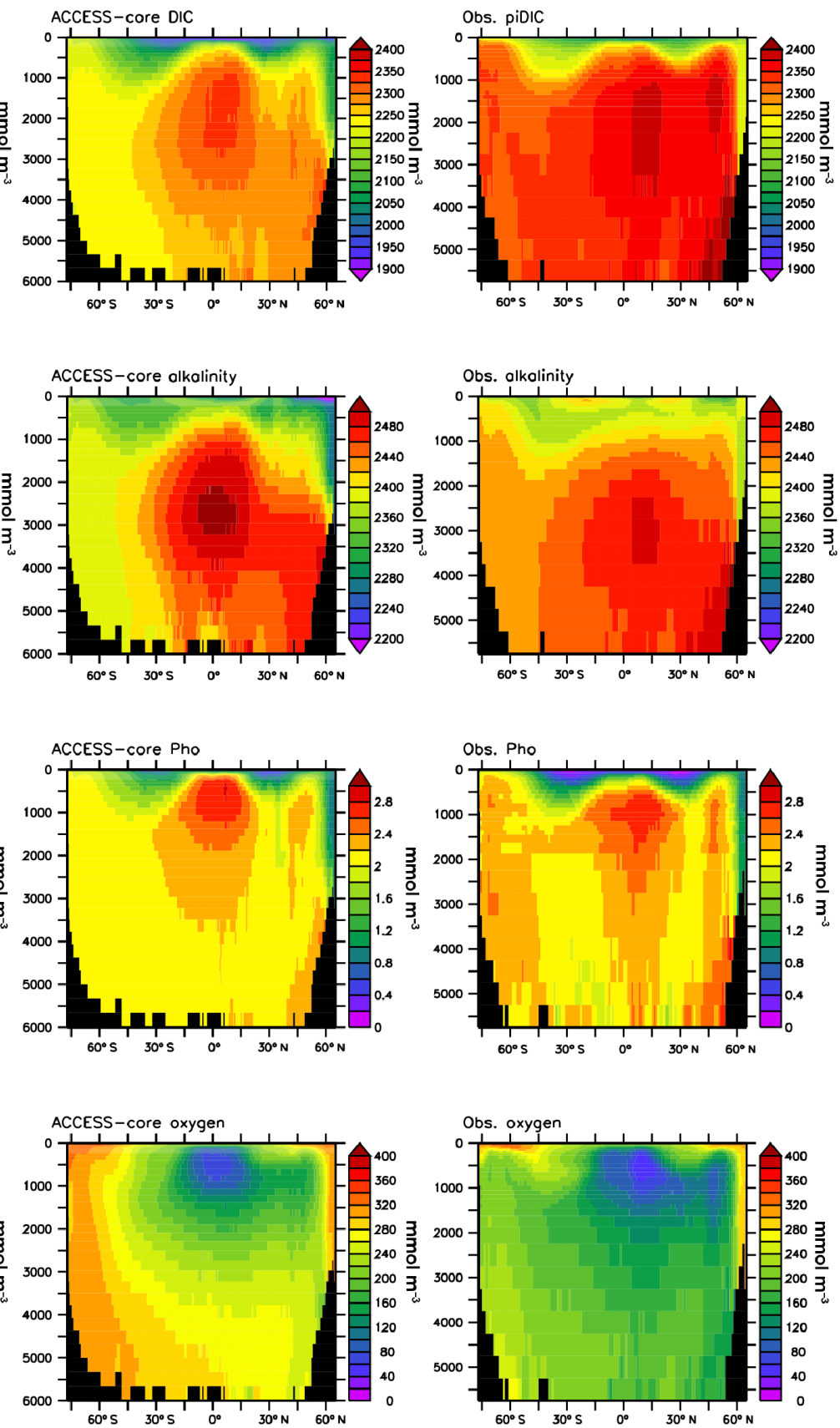

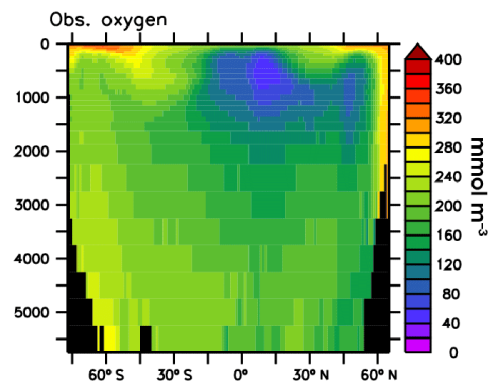

Figure 11. Zonal-averaged sections of ACCESS-ESM1 simulation for the years 901-1000 (left) compared to an ocean-only simulation with CORE forcing (centre) and the observations (right) for (a) DIC in mmol $\mathrm{Cm}^{-3}$, (b) Alkalinity in $\mathrm{mmol} \mathrm{Eq} \mathrm{m}^{-3}$, (c) Phosphate in mmol $\mathrm{Pm}^{-3}$ and (d) Oxygen in $\mathrm{mmolOm}^{-3}$.

LAI case. The strong positive correlations in the mid-latitude ocean reveal that most of the variability in these regions occurs on timescales longer than 1 year. While in the equatorial Pacific where the lagged correlation is negative, variability on timescales shorter than a year starts to be important. The larger positive correlations for ProgLAI land fluxes are mainly located in semi-arid regions. Larger correlations for
ProgLAI are expected; a year of large GPP and consequently more carbon uptake will lead to increased LAI and a tendency to maintaining large GPP and carbon uptake in the following year. The location of the larger correlations suggests this process is most important for regions where the vegetation is more marginal. 

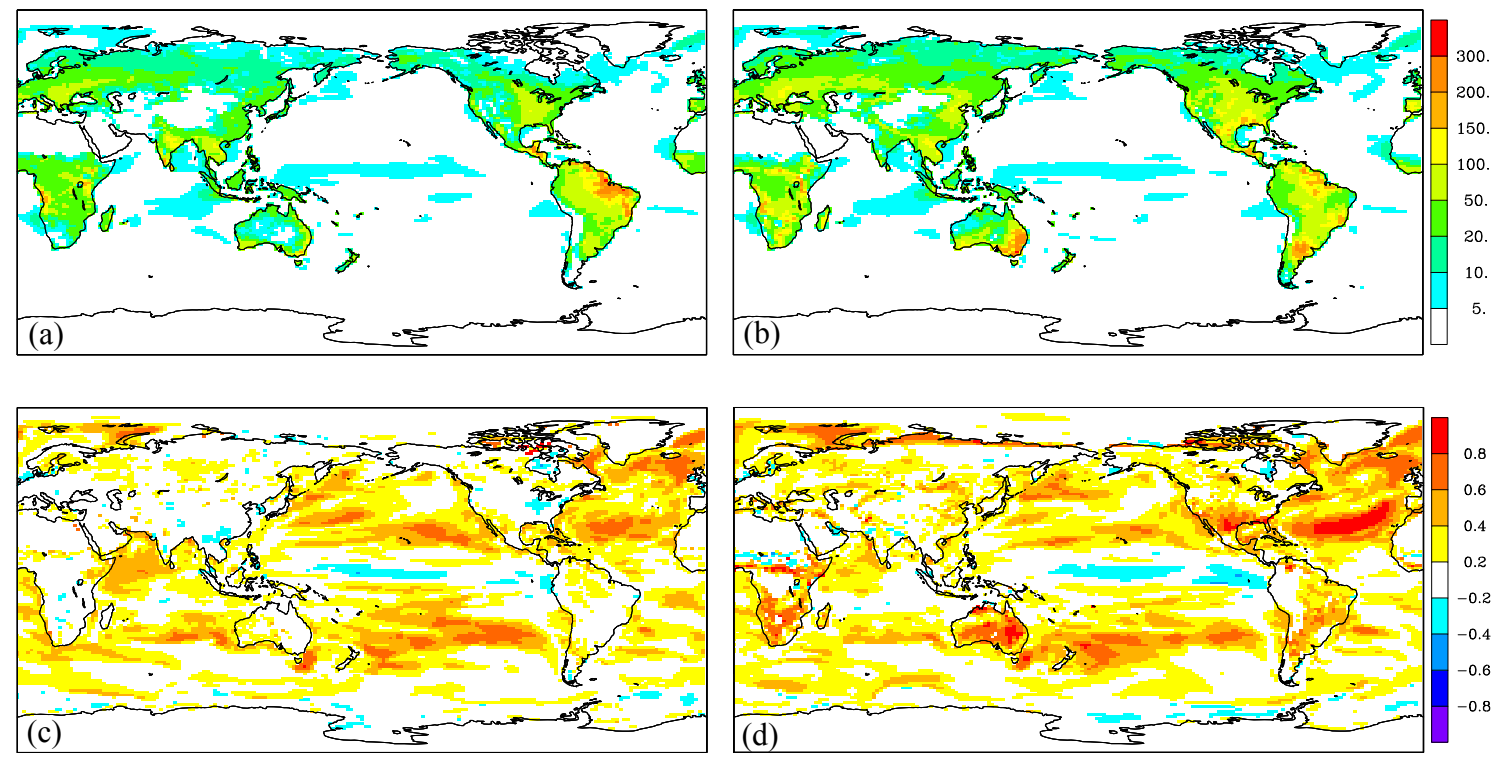

Figure 12. Standard deviation of carbon flux to the atmosphere $(\mathbf{a}, \mathbf{b})$ in $\mathrm{g} \mathrm{C}^{-2} \mathrm{yr}^{-1}$ for years $901-1000$ and the autocorrelation for carbon flux with 1-year lag (c, d) for PresLAI (left) and ProgLAI (right).
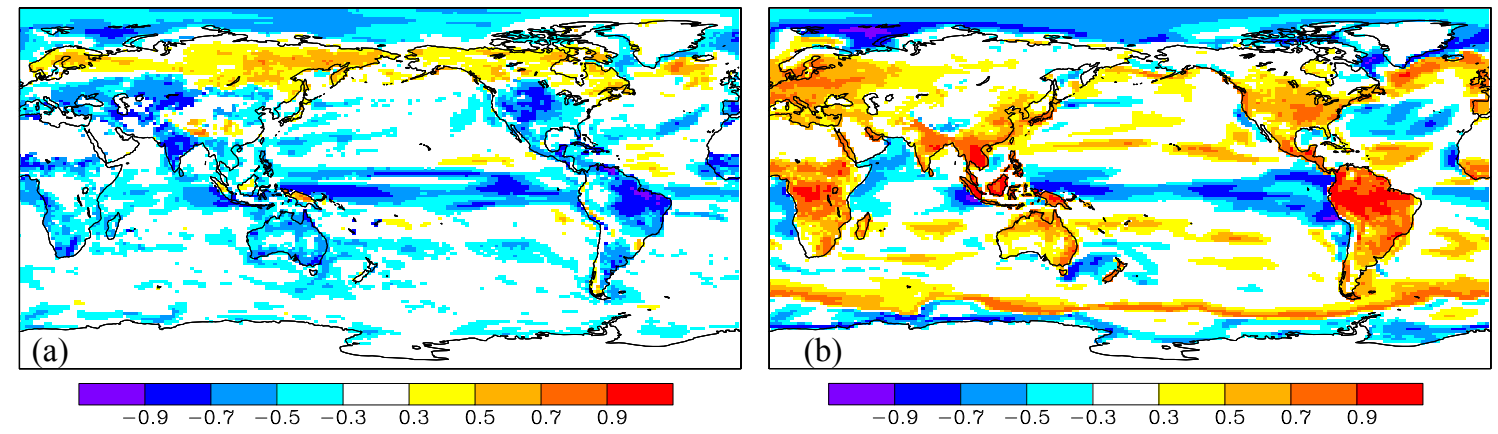

Figure 13. Correlation between annual carbon flux to the atmosphere and (a) annual mean precipitation and (b) annual mean screen-level temperature for years 901-1000 from the ProgLAI simulation.

Table 2. Standard deviation of annual global carbon flux for years 901-1000 in $\mathrm{PgC} \mathrm{yr}^{-1}$.

\begin{tabular}{lrr}
\hline & PresLAI & ProgLAI \\
\hline GPP & 1.17 & 1.87 \\
Leaf resp & 0.26 & 0.75 \\
Plant resp & 0.17 & 0.27 \\
Soil resp & 0.27 & 0.32 \\
NEE & 1.40 & 1.21 \\
\hline
\end{tabular}

The impact of climate variability on carbon flux to the atmosphere is seen in Fig. 13, which shows the correlation between carbon flux and precipitation or screen-level temperature for the ProgLAI case. The correlations are similar in pattern for PresLAI and, for the land carbon flux at least, generally slightly stronger than for ProgLAI (suggesting that in ProgLAI the interannual variability driven by climate is slightly moderated by the autocorrelation in NEE generated by LAI variability). For the ocean carbon flux the correlation with precipitation is generally low except for more negative correlations along the Equator and across the Arctic Ocean. For land, there are strong negative correlations with precipitation in regions where the rainfall is generally lower and plant growth is water limited, such as at the margins of deserts. In the northern high latitudes the correlation with precipitation becomes positive. With water limitation unlikely in this region, low precipitation is likely associated with less cloud and more sunshine leading to greater photosynthesis and more negative NEE.

The correlation with temperature is positive almost everywhere for the land-air carbon flux but more variable for the sea-air carbon flux. For the ocean, negative correlation is found in tropical regions where outgassing occurs while posi- 
tive correlations are found around the sea-ice edge. Along the Equator, the warming of the surface temperature is associated with El Niños and the decreased supply of carbon-rich intermediate water to the surface ocean, which reduces the sea-air flux of carbon. Along the sea-ice edge, the surface warming helps to reduce sea-ice and carbon solubility leading to increased sea-air flux with increased surface temperatures. For the land, the largest correlation is in the tropics. Ciais et al. (2013, Fig. 6.17) presents the sensitivity of interannual variations in global land carbon sink to interannual variations in global land temperature and precipitation for 1980 2009, showing a large range of sensitivities across models. While not directly comparable, sensitivities calculated from the ProgLAI simulation are mostly within the range of other models but also seem quite sensitive to the time period over which the calculation is performed.

\section{Conclusion and future model development}

The key components and features of ACCESS-ESM1 have been described. CABLE simulates land carbon fluxes and pools, with the capability of accounting for nitrogen and phosphorus limitation. Leaf area index can be simulated, although phenology is prescribed. Inputs to the land carbon system e.g. nitrogen fixation are fixed and there is also no change in vegetation distribution. Thus, we do not account for land use change over the historical period. WOMBAT simulates ocean carbon biogeochemistry of DIC, Alkalinity, phosphate, iron and oxygen with single phytoplankton and zooplankton compartments. The growth of the phytoplankton is limited by phosphate, iron and light and the phytoplankton produce a fixed fraction of calcium carbon to organic carbon.

This paper has described the behaviour of ACCESS-ESM1 for the relatively simple case of pre-industrial conditions with prescribed atmospheric $\mathrm{CO}_{2}$. A second part of this study (Ziehn et al., 2017) evaluates the model over the historical period, again with prescribed atmospheric $\mathrm{CO}_{2}$. Two ACCESS-ESM1 simulations were compared; both used the same ocean biogeochemistry and the land carbon module with nutrient limitation ( $\mathrm{N}$ and $\mathrm{P}$ ) active but one used prescribed LAI and the other prognostic LAI. Simulating LAI (ProgLAI) increased interannual variability in GPP and respiration fluxes, but not in global total NEE, and also gave a slight warming of the climate. ProgLAI tended to underestimate the LAI in the tropics and overestimate LAI at high latitudes, compared to the dataset used in the prescribed LAI case. The different LAI distribution impacted the spatial distribution and seasonal cycle of carbon fluxes. Despite the apparent biases in the simulation of leaf area index (in ProgLAI), this is our preferred configuration because it is important that LAI is responsive to climate, especially for scenario simulations out to 2100 . For ocean carbon, we see reasonable agreement with observations The spatial pattern of pre-industrial sea-air carbon fluxes shows good agreement with published studies. Global primary productivity is close to the observed value although the spatial distribution does not match observations well.

Analysis of the pre-industrial simulation has highlighted some critical issues with the ACCESS-ESM1 carbon models and how biases in the physical model simulation can contribute to a poor simulation of carbon fluxes. For land carbon, a high priority is to fix the inability of CABLE to conserve carbon in (localized) regions where moisture is insufficient to maintain vegetation. A solution has been developed for the stand-alone version of CABLE, but its effectiveness in the coupled version is still being assessed. However, even when carbon conservation is resolved, the coupled system may still respond poorly in regions where the physical model significantly underestimates rainfall and carbon pools become depleted. This was particularly noticeable for the $\mathrm{C} 4$ grass vegetation type. Work being undertaken with the standalone version of CABLE to allow the phenology of grasses to be soil-moisture and temperature dependent (V. Haverd, personal communication, 2016) may help to improve this aspect of the simulation. Key outstanding issues to be addressed in the ocean are

a. values of ocean primary productivity, bringing them closer to the observations;

b. reducing the excess of surface phosphate, potentially through modifying the particulate organic carbon export;

c. reducing the export of calcium carbonate to improve interior alkalinity concentrations.

It is clear from our simulations that our model has yet to fully reach quasi-steady state, despite more than 1000 years of simulation, with a global sea-air flux still greater than $0.55 \mathrm{PgCyr}^{-1}$. This slow equilibration, along with the localized land carbon non-conservation, means that ACCESSESM1 is not yet suitable for running emissions-driven simulations, unless a carbon flux correction is applied. Prescribed atmospheric $\mathrm{CO}_{2}$ simulations remain useful and analysis is being undertaken of a range of RCP simulations out to 2100 .

At present, computational limitations inhibit our ability to optimize the model behaviour and produce carbon fields that are equilibrated with the pre-industrial atmosphere. Therefore, in the longer term, we need to develop better ways to tune the carbon models and accelerate the convergence of both the land and ocean carbon models to steady state (e.g. Fang et al., 2015). We also need to work closely with those developing the physical model components of ACCESS, since the quality of the carbon simulation is dependent on the quality of the physical model simulation.

Development priorities for CABLE in future ACCESSESM versions are implementation of land use change, the ability for phenology to respond to climate and improved 
nutrient forcing (e.g. temporally varying input fluxes). For WOMBAT, we see a recognized need to add additional complexity, in terms of phytoplankton and zooplankton classes, to capture the potential impacts related to projected changes in the marine environment such as ocean acidification (e.g. Matear and Lenton, 2014).

At present the next physical model version of ACCESS (ACCESS-CM2) is currently being developed in preparation for CMIP6. The land and ocean carbon cycles presented here will form the basis for ACCESS-ESM2, once we have resolved the critical deficiencies that this study has elucidated.
Code availability. Code availability varies for different components of ACCESS-ESM1. The UM is licensed by the UK Met Office and is not freely available. CABLE2 is available from https://trac. nci.org.au/svn/cable/ following registration. See https://trac.nci.org. $\mathrm{au} / \mathrm{trac} / \mathrm{cable} /$ wiki/CableRegistration for information on registering to use the CABLE repository. MOM4p1 and CICE are freely available under applicable registration or copyright conditions. For MOM4p1 see https://github.com/BreakawayLabs/MOM4p1. For CICE see http://oceans11.lanl.gov/trac/CICE. For access to the MOM4p1 code with WOMBAT as used for ACCESS-ESM1, please contact Matt Chamberlain (Matthew.Chamberlain@csiro.au). The OASIS3-MCT 2.0 coupler code is available from http://oasis.enes. org. 


\section{Appendix A: ACCESS1.4 compared to ACCESS1.3}

Details of model code differences between the published ACCESS1.3 version (Bi et al., 2013b) and the physical model version used here (ACCESS1.4) are noted for each model component (Fig. 1). The impact of these changes on the preindustrial climate model simulation is also noted.

\section{A1 Atmosphere component}

ACCESS1.3 used atmospheric physics settings similar to the Met Office Global Atmosphere (GA) 1.0 configuration (Hewitt et al., 2011) including the "PC2" cloud scheme (Wilson et al., 2008). A similar configuration is used for ACCESS1.4.

Analysis of ACCESS1.3 simulations showed almost no dust in the atmosphere (Dix et al., 2013); this was a consequence of changing the land surface scheme from the original UM land scheme to CABLE and freezing the ACCESS1.3 code version for CMIP5 before finalising dust settings. As described in Dix et al. (2013), the dust-uplift scheme used in the ACCESS models is based on Woodward (2001) and Woodward (2011), with dust being modelled for nine size bins with different particle diameters. Dust uplift can occur over bare soil and depends on wind speed, soil composition and volumetric soil-moisture content in the surface layer. Dust-uplift settings used by ACCESS1.4 for the tuneable parameters described in Woodward (2011) are friction-velocity tuneable constant $k_{1}=1.6$, soil-moisture tuneable constant $k_{2}=0.5$, overall scaling factor $C=6.525$, maximum clay fraction for dust emissions of 0.1 and no preferential source term. These settings result in a global annual mean dust burden of $14.9 \pm 1.3 \mathrm{Tg}$ (calculated over 160 years from an ACCESS1.4 pre-industrial control simulation), which is broadly comparable to the AEROCOM multi-model median value of $15.8 \mathrm{Tg}$ for year 2000 conditions (Huneeus et al., 2011).

In addition to the change in dust, the ACCESS1.3 control simulation did not include background stratospheric volcanic forcing but this has been included in ACCESS1.4 simulations. Preliminary tests with the dust and volcanic forcing changes reduced the globally averaged surface air temperature relative to ACCESS1.3. Since an aim of ACCESS1.4 was not to change global-scale climate characteristics relative to ACCESS1.3, one of the parameters in the cloud scheme (FW_STD associated with the standard deviation of cloud water content) was increased from 0.700 in ACCESS1.3 to 0.725 in ACCESS1.4. This resulted in a globally averaged surface air temperature in ACCESS1.4 that was similar to that obtained for ACCESS1.3. ACCESS1.4 also corrects a bug, which zeroed the downward short-wave radiation over coastal sea-ice points for non-radiation time steps. This reduced excess ice accumulation in ACCESS1.3 in some coastal regions such as the Canadian Archipelagos.

\section{A2 Land component}

CABLE was implemented in ACCESS1.3 at version 1.8 (CABLE1.8, Kowalczyk et al., 2013) while ACCESS1.4 uses CABLE2.2.3. CABLE2.2.3 has a number of small science changes and bug fixes from CABLE1.8. These dealt with occasional non-physical exchange coefficients, addressed some poor behaviour under very dry conditions, improved the water balance in the coupled system and ensured all CABLE variables were correctly being passed back into the ACCESS atmosphere, e.g. for use by dry deposition. CABLE in ACCESS1.3 used a constant (370 ppm) (internal to CABLE) atmospheric $\mathrm{CO}_{2}$ for all simulations while ACCESS1.4 correctly passes the atmospheric $\mathrm{CO}_{2}$ from the UM to CABLE. Often these changes could be shown to improve CABLE's performance in stand-alone mode for individual locations (e.g. at desert sites for the dry condition changes) but did not have broad-scale impacts when tested globally in atmosphere-only ACCESS simulations. Thus, the assessment of the land surface impacts on the ACCESS climate for ACCESS1.3 (Kowalczyk et al., 2013) would also be applicable to ACCESS1.4 simulations. The improvements to the water balance approximately halved the drift in global ocean salinity in ACCESS1.4 compared to ACCESS1.3.

\section{A3 Ocean component}

While there are no changes in the ocean model version between ACCESS1.3 and ACCESS1.4, there have been two changes in the configuration or parameter values. First, for ACCESS1.4, the background vertical diffusivity outside $20^{\circ} \mathrm{S}$ to $20^{\circ} \mathrm{N}$ has been increased from $0.5 \times 10^{-5}$ to $1.0 \times$ $10^{-5} \mathrm{~m}^{2} \mathrm{~s}^{-1}$, which is also consistent with the value used in ACCESS-OM. Second, the ocean absorption of penetrative solar radiation is now calculated using the diffuse attenuation coefficient of the downwelling photosynthetically available radiation $\left(K_{\mathrm{dPAR}}\right)$ rather than the downwelling spectral irradiance at wavelength $490 \mathrm{~nm}\left(K_{\mathrm{d} 490}\right)$. Since $K_{\mathrm{dPAR}}$ data covers a broader, more representative, spectrum of light, it is considered to be more appropriate for use in the ocean model and was also the dataset used in the standard ACCESS-OM configuration. Bi et al. (2013a) compared ACCESS-OM simulations using $K_{\mathrm{dPAR}}$ and $K_{\mathrm{d} 490}$ and concluded that differences are mostly confined to the subsurface water between $40^{\circ} \mathrm{S}$ to $40^{\circ} \mathrm{N}$ with little impact on the deep ocean climate or the global ocean circulation and associated water volume transports.

\section{A4 OASIS coupler}

ACCESS1.3 used the OASIS3.2-5 coupler (Valcke, 2006). In ACCESS1.4, this is replaced by OASIS3-MCT (Valcke et al., 2013), which is designed to provide more efficient coupling for models running on many processors. For ACCESS1.4, this enables the simulation of about 7.2 model years per day 


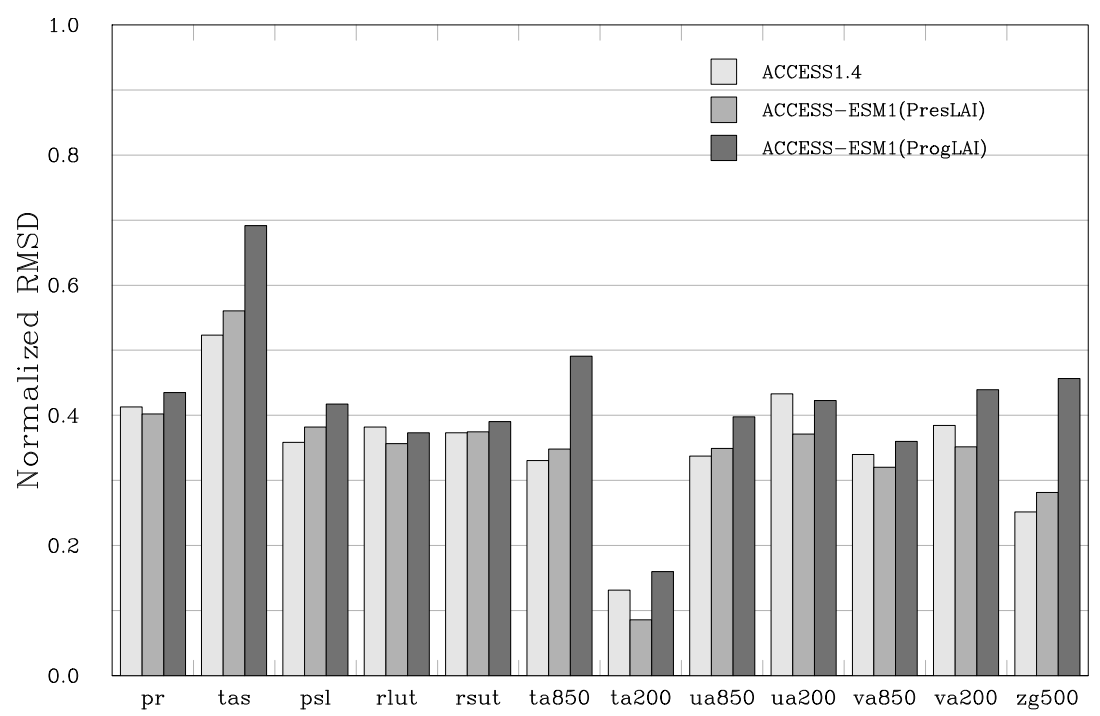

Figure A1. Root mean square difference (RMSD) between atmospheric variables simulated by the model versions listed in the key and those from the ACCESS1.3 pre-industrial simulation normalized by the RMSD between ACCESS1.0 and ACCESS1.3. The variables are precipitation (pr), surface air temperature (tas), sea level pressure (psl), top of atmosphere long-wave radiation (rlut), top of atmosphere reflected short-wave radiation (rsut), air temperature (ta), zonal (ua) and meridional wind (va) at 850 and $200 \mathrm{hPa}$ and geopotential height (zg) at $500 \mathrm{hPa}$.

(using 144 processors) compared to 5.4 model years per day for ACCESS1.3.

\section{A5 Comparison of pre-industrial climate across ACCESS versions}

The two ACCESS submissions to CMIP5, ACCESS1.0 and ACCESS1.3 produced similar results, relative to the range of CMIP5 models, when various modelled atmospheric climate variables were compared against observations (e.g. Flato et al., 2013, Fig. 9.7). Here we show that ACCESS1.4 (and ACCESS-ESM1) simulations are more similar to ACCESS1.3 than ACCESS1.0 was to ACCESS1.3. We use monthly mean values averaged across 100 years from preindustrial climate simulations and calculate the root mean square difference (RMSD), similar to Gleckler et al. (2008), between each modelled field $(F)$ and that modelled by ACCESS1.3 $(R)$. The RMSD is calculated across all longitude $(i)$ and latitude $(j)$ and, depending on the variable, at different pressure levels:

$\mathrm{RMSD}^{2}=\frac{1}{W} \sum_{i} \sum_{j} \sum_{t} w_{i j t}\left(F_{i j t}-R_{i j t}\right)^{2}$,

where $t$ corresponds to the time dimension (12 months) and $W$ is the sum of the weights $\left(w_{i j t}\right)$, which, for the spatial domain, are proportional to the grid-cell area. We then normalize by the ACCESS1.0 RMSD:

$\mathrm{RMSD}_{\text {norm }}=\mathrm{RMSD}_{\text {model }} / \mathrm{RMSD}_{\mathrm{ACCESS} 1.0}$

such that a value of 1 indicates that the simulated variable is as different from ACCESS1.3 as ACCESS1.0 is from AC-
CESS1.3 while values smaller than 1 indicate a simulation that is closer to that of ACCESS1.3.

Figure A1 shows that for a range of atmospheric variables the normalized RMSD for ACCESS1.4 is generally around 0.3-0.4 indicating that the ACCESS1.4 climate simulation is much closer to ACCESS1.3 than ACCESS1.0 is to ACCESS1.3. This would be expected given the relatively small number of science changes between ACCESS1.3 and ACCESS1.4. Likewise, the ACCESS-ESM1 simulation with prescribed LAI shows similar RMSDs from ACCESS1.3, implying little or no change from the ACCESS1.4 simulation when the carbon cycle is included but the atmospheric $\mathrm{CO}_{2}$ is prescribed. The RMSDs for ACCESS-ESM1 with prognostic LAI are generally similar or slightly larger than for the case with prescribed LAI, with the largest differences being for near-surface and lower tropospheric temperature and geopotential height at $500 \mathrm{hPa}$. 


\section{The Supplement related to this article is available online at https://doi.org/10.5194/gmd-10-2567-2017- supplement.}

Competing interests. The authors declare that they have no conflict of interest.

Acknowledgements. This research was supported by the Australian Government Department of the Environment, the Bureau of Meteorology and CSIRO through the Australian Climate Change Science Programme. The research was undertaken on the NCI National Facility in Canberra, Australia, which is supported by the Australian Commonwealth Government. The authors wish to acknowledge use of the Ferret program for some of the analysis and graphics in this paper. Ferret is a product of NOAA's Pacific Marine Environmental Laboratory (information is available at http://ferret.pmel.noaa.gov/Ferret/). Ashok Luhar provided helpful feedback on the manuscript. Mark Collier implemented the PCDMI metrics package, which was used for the comparison of atmospheric variables between ACCESS model versions. Arnold Sullivan helped produce some of the figures.

Edited by: Didier Roche

Reviewed by: four anonymous referees

\section{References}

Anav, A., Friedlingstein, P., Kidston, M., Bopp, L., Ciais, P., Cox, P., Jones, C., Jung, M., Myneni, R., and Zhu, Z.: Evaluating the land and ocean components of the global carbon cycle in the CMIP5 Earth System Models, J. Clim., 26, 6801-6843, 2013.

Arora, V. K., Boer, G. J., Friedlingstein, P., Eby, M., Jones, C. D., Christian, J. R., Bonan, G., Bopp, L., Brovkin, V., Cadule, P., Hajima, T., Ilyina, T., Lindsay, K., Tjiputra, J. F., and Wu, T.: Carbon-concentration and carbon-climate feedbacks in CMIP5 Earth System Models, J. Clim., 26, 5289-5314, 2013.

Behrenfeld, M. J. and Falkowski, P. G.: Photosynthetic rates derived from satellite-based chlorophyll concentration, Limnol. Oceanogr., 42, 1-20, 1997.

Bi, D., Marsland, S. J., Uotila, P., O'Farrell, S., Fiedler, R., Sullivan, A., Griffies, S. M., Zhou, X., and Hirst, A. C.: ACCESSOM: the ocean and sea-ice core of the ACCESS coupled model, Aust. Meteor. Oceanogr. J., 63, 213-232, 2013a.

Bi, D., Dix, M., Marsland, S. J., O’Farrell, S., Rashid, H. A., Uotila, P., Hirst, A. C., Kowalczyk, E., Golebiewski, M., Sullivan, A., Yan, H., Hannah, N., Franklin, C., Sun, Z., Vohralik, P., Watterson, I., Zhou, X., Fiedler, R., Collier, M., Ma, Y., Noonan, J., Stevens, L., Uhe, P., Zhu, H., Griffies, S. M., Hill, R., Harris, C., and Puri, K.: The ACCESS coupled model: description, control climate and evaluation, Aust. Meteor. Oceanogr. J., 63, 41-64, 2013b.

Boer, G. J. and Arora, V. K.: Feedbacks in emission-driven and concentration-driven global carbon budgets, J. Clim., 26, 33263314, https://doi.org/10.1175/JCLI-D-12-00365.1, 2012.
Carr, M.-E., Friedrichs, M. A. M., Schmeltz, M., Aita, M. N., Antoine, D., Arrigo, K. R., Asanuma, I., Aumont, O., Barber, R., Behrenfeld, M., Bidigare, R., Buitenhuis, E., Campbell, J., Ciotti, A., Dierssen, H., Dowell, M., Dunne, J., Esaias, W., Gentili, B., Gregg, W., Groom, S., Hoepffner, N., Ishizaka, J., Kameda, T., Le Quéré, C., Lohrenz, S., Marra, J., Mélin, F., Moore, J., Morel, A., Reddy, T. E., Ryan, J., Scardi, M., Smyth, T., Turpie, K., Tilstone, G., Waters, K., and Yamanaka, Y.: A comparison of global estimates of marine primary production from ocean color, Deep-Sea Res. Pt. II, 53, 741770, 2006.

Ciais, P., Sabine, C., Bala, G., Bopp, L., Brovkin, V., Canadell, J., Chhabra, A., DeFries, R., Galloway, J., Heimann, M., Jobes, C., Le Quéré, C., Myneni, R. B., Piao, S., and Thornton, P.: Carbon and other biogeochemical cycles, in: Climate Change 2013: The Physical Science Basis. Contribution of Working Group I to the Fifth Assessment Report of the Intergovernmental Panel on Climate Change, edited by: Stocker, T. F., Qin, D., Plattner, G.K., Tignor, M., Allen, S. K., Boschung, J., Nauels, A., Xia, Y., Bex, V., and Midgley, P. M., Cambridge University Press, Cambridge, UK and New York, NY, USA, 465-570, 2013.

Comiso, J.: Bootstrap Sea Ice Concentrations from Nimbus-7 SMMR and DMSP SSM/I-SSMIS, Version 2, [1978-2007], National Snow and Ice Data Center, 2000 (updated 2012).

Cox, P. D., Betts, R. A., Jones, C. D., Spall, S. A., and Totterdell, I. J.: Acceleration of global warming due to carbon-cycle feedbacks in a coupled climate model, Nature, 408, 184-187, 2000.

Dix, M., Vohralik, P., Bi, D., Rashid, H., Marsland, S., O'Farrell, S., Uotila, P., Hirst, T., Kowalczyk, E., Sullivan, A., Yan, H., Franklin, C., Sun, Z., Watterson, I., Collier, M., Noonan, J., Rotstayn, L., Stevens, L., Uhe, P., and Puri, K.: The ACCESS coupled model: documentation of core CMIP5 simulations and initial results, Aust. Meteor. Oceanogr. J., 63, 83-99, 2013.

Eppley, R. W.: Temperature and phytoplankton growth in the sea, Fish. Bull. US, 70, 1063-1085, 1972.

Exbrayat, J.-F., Pitman, A. J., Abramowitz, G., and Wang, Y.-P.: Sensitivity of net ecosystem exchange and heterotrophic respiration to parameterization uncertainty, J. Geophys. Res.-Atmos., 118, 1-12, https://doi.org/10.1029/2012JD018122, 2013.

Fang, Y., Liu, C., and Leung, L. R.: Accelerating the spin-up of the coupled carbon and nitrogen cycle model in CLM4, Geosci. Model Dev., 8, 781-789, https://doi.org/10.5194/gmd-8781-2015, 2015.

Flato, G., Marotzke, J., Abiodun, B., Braconnot, P., Chou, S., Collins, W., Cox, P., Driouech, F., Emori, S., Eyring, V., Forest, C., Gleckler, P., Guilyardi, E., Jakob, C., Kattsov, V., Reason, C., and Rummukainen, M.: Evaluation of Climate Models, in: Climate Change 2013: The Physical Science Basis. Contribution of Working Group I to the Fifth Assessment Report of the Intergovernmental Panel on Climate Change, edited by: Stocker, T. F., Qin, D., Plattner, G.-K., Tignor, M., Allen, S., Boschung, J., Nauels, A., Xia, Y., Bex, V., and Midgley, P., 741-866, Cambridge University Press, Cambridge, UK and New York, NY, USA, 2013.

Friedlingstein, P., Bopp, L., Ciais, P., Dufresne, J.-L., Fairhead, L., LeTreut, H., Monfray, P., and Orr, J.: Positive feedback between future climate change and the carbon cycle, Geophys. Res. Lett., 28, 1543-1546, 2001. 
Friedlingstein, P., Cox, P., Betts, R., Bopp, L., von Bloch, W., Brovkin, V., Cadule, P., Doney, S., Eby, M., Fung, I., Bala, G., John, J., Jones, C., Joos, F., Kato, T., Kawamiya, M., Knorr, W., Lindsay, K., Matthews, H. D., Raddatz, T., Rayner, P., Reick, C., Roeckner, E., Schnitzler, K.-G., Schnur, R., Strassmann, K., Weaver, A. J., Yoshikawa, C., and Zeng, N.: Climate-carbon cycle feedback analysis: results from the $\mathrm{C}^{4}$ MIP model intercomparison, J. Climate, 19, 3337-3353, https://doi.org/10.1175/JCLI3800.1, 2006.

Friedlingstein, P., Meinshausen, M., Arora, V. K., Jones, C. D., Anav, A., Liddicoat, S. K., and Knuitti, R.: Uncertainties in CMIP5 climate projections due to carbon cycle feedbacks, J. Clim., 27, 511-526, 2014.

Garcia, H., Locarnini, R., and Boyer, T.: World ocean atlas 2005, Volume 3: Dissolved oxygen, apparent oxygen utilization, in: NOAA Atlas NESDIS 63, edited by: Levitus, S., US Government Printing Office, Washington, DC, 342 pp., 2006a.

Garcia, H., Locarnini, R., Boyer, T., and Antonov, J.: World ocean atlas 2005, Volume 4: Nutrients (phosphate, nitrate, silicate), in: NOAA Atlas NESDIS 63, edited by: Levitus, S., US Government Printing Office, Washington, DC, 396 pp., 2006b.

Gleckler, P. J., Taylor, K. E., and Doutriaux, C.: Performance metrics for climate models, J. Geophys. Res., 113, D06104, https://doi.org/10.1029/2007JD008972, 2008.

Griffies, S. M.: Elements of MOM4p1, GFDL Ocean Group, Tech. Rep. No. 6, NOAA/Geophysical Fluid Dynamics Laboratory, Princeton, USA, 2009.

Gruber, N., Gloor, M., Fletcher, S. E. M., Doney, S. C., Dutkiewicz, S., Follows, M. J., Gerber, M., Jacobson, A. R., Joos, F., Lindsay, K., Menemenlis, D., Mouchet, A., Muller, S. A., Sarmiento, J. L., and Takahashi, T.: Oceanic sources, sinks, and transport of atmospheric $\mathrm{CO}_{2}$, Global Biogeochem. Cy., 23, GB1005, https://doi.org/10.1029/2008gb003349, 2009.

Hewitt, H. T., Copsey, D., Culverwell, I. D., Harris, C. M., Hill, R. S. R., Keen, A. B., McLaren, A. J., and Hunke, E. C.: Design and implementation of the infrastructure of HadGEM3: the next-generation Met Office climate modelling system, Geosci. Model Dev., 4, 223-253, https://doi.org/10.5194/gmd-4-2232011, 2011.

Huang, M., Piao, S., Sun, Y., Ciais, P., Cheng, L., Mao, J., Poulter, B., Shi, X., Zeng, Z., and Wang, Y.: Change in terrestrial ecosystem water-use efficiency over the last three decades, Glob. Change Biol., 21, 2366-2378, https://doi.org/10.1111/gcb.12873, 2015.

Huneeus, N., Schulz, M., Balkanski, Y., Griesfeller, J., Prospero, J., Kinne, S., Bauer, S., Boucher, O., Chin, M., Dentener, F., Diehl, T., Easter, R., Fillmore, D., Ghan, S., Ginoux, P., Grini, A., Horowitz, L., Koch, D., Krol, M. C., Landing, W., Liu, X., Mahowald, N., Miller, R., Morcrette, J.-J., Myhre, G., Penner, J., Perlwitz, J., Stier, P., Takemura, T., and Zender, C. S.: Global dust model intercomparison in AeroCom phase I, Atmos. Chem. Phys., 11, 7781-7816, https://doi.org/10.5194/acp11-7781-2011, 2011.

Hunke, E. C. and Lipscomb, W. H.: CICE: The Los Alamos sea ice model documentation and software user's manual, Version 4.1, LA-CC-06-012, Los Alamos National Laboratory, NM, 2010.

Jones, C., Robertson, E., Arora, V., Friedlingstein, P., Shevliakova, E., Bopp, L., Brovkin, V., Hajima, T., Kato, E.,
Kawamiya, M., Liddicoat, S., Lindsay, K., Reick, C. H., Roelandt, C., Segschneider, J., and Tjiputra, J.: Twenty-first-century compatible $\mathrm{CO}_{2}$ emissions and airborne fraction simulated by CMIP5 Earth System Models under four representative concentration pathways, J. Clim., 26, 4398-4413, 2013.

Jones, C. D., Hughes, J. K., Bellouin, N., Hardiman, S. C., Jones, G. S., Knight, J., Liddicoat, S., O'Connor, F. M., Andres, R. J., Bell, C., Boo, K.-O., Bozzo, A., Butchart, N., Cadule, P., Corbin, K. D., Doutriaux-Boucher, M., Friedlingstein, P., Gornall, J., Gray, L., Halloran, P. R., Hurtt, G., Ingram, W. J., Lamarque, J.-F., Law, R. M., Meinshausen, M., Osprey, S., Palin, E. J., Parsons Chini, L., Raddatz, T., Sanderson, M. G., Sellar, A. A., Schurer, A., Valdes, P., Wood, N., Woodward, S., Yoshioka, M., and Zerroukat, M.: The HadGEM2-ES implementation of CMIP5 centennial simulations, Geosci. Model Dev., 4 , 543-570, https://doi.org/10.5194/gmd-4-543-2011, 2011.

Jones, P. and Harris, I.: CRU TS3.22: Climatic Research Unit (CRU) Time-Series (TS) Version 3.22 of High Resolution Gridded Data of Month-by-month Variation in Climate (January 1901-December 2013), https://doi.org/10.5285/18BE23F8D252-482D-8AF9-5D6A2D40990C, 2014.

Kattge, J., Knorr, W., Raddatz, T., and Wirth, C.: Quantifying photosynthetic capacity and its relationship to leaf nitrogen content for global-scale terrestrial biosphere models, Glob. Change Biol., 15, 976-991, https://doi.org/10.1111/j.1365-2486.2008.01744.x, 2009.

Kelly, R. H., Parton, W. J., Hartman, M. D., Stretch, L. K., Ojima, D. S., and Schimel, D. S.: Intra-annual and interannual variability of ecosystem processes in shortgrass steppe, J. Geophys. Res., 105, 20093-20100, https://doi.org/10.1029/2000JD900259, 2000.

Key, R. M., Kozyr, A., Sabine, C. L., Lee, K., Wanninkhof, R., Bullister, J. L., Feely, R. A., Millero, F. J., Mordy, C., and Peng, T. H.: A global ocean carbon climatology: results from Global Data Analysis Project (GLODAP), Global Biogeochem. Cy., 18, GB4031, https://doi.org/10.1029/2004GB002247, 2004.

Kowalczyk, E. A., Wang, Y. P., Law, R. M., Davies, H. L., McGregor, J. L., and Abramowitz, G.: The CSIRO Atmosphere Biosphere Land Exchange (CABLE) model for use in climate models and as an offline model, CSIRO Marine and Atmospheric Research technical paper 13, Aspendale, Victoria, Australia, 2006.

Kowalczyk, E. A., Stevens, L., Law, R. M., Dix, M., Wang, Y. P., Harman, I. N., Haynes, K., Srbinovsky, J., Pak, B., and Ziehn, T.: The land surface model component of ACCESS: description and impact on the simulated surface climatology, Aust. Meteor. Oceanogr. J., 63, 65-82, 2013.

Large, W. and Yeager, S. G.: Diurnal to decadal global forcing for ocean and Sea-Ice models: The data sets and flux climatologies, Tech. Rep. NCAR/TN-460+STR, 2004.

Lawrence, P. J., Feddema, J. J., Bonan, G. B., Meehl, G. A., O'Neill, B. C., Oleson, K. W., Levis, S., Lawrence, D. M., Kluzek, E., Lindsay, K., and Thornton, P. E.: Simulating the biogeochemical and biogeophysical impacts of transient land cover change and wood harvest in the Community Climate System Model (CCSM4) from 1850 to 2100, J. Clim., 25, 3071-3095, https://doi.org/10.1175/JCLI-D-11-00256.1, 2012.

Lenton, A. and Matear, R. J.: Role of the Southern Annular Mode (SAM) in Southern Ocean $\mathrm{CO}_{2}$ uptake, Global Biogeochem. Cy., 21, GB2016, https://doi.org/10.1029/2006GB002714, 2007. 
Marsland, S. J., Bi, D., Uotila, P., Fiedler, R., Griffies, S. M., Lorbacher, K., O'Farrell, S., Sullivan, A., Uhe, P., Zhou, X., and Hirst, A. C.: Evaluation of ACCESS climate model ocean diagnostics in CMIP5 simulations, Aust. Meteor. Oceanogr. J., 63, 101-119, 2013.

Martin, G. M., Milton, S. F., Senior, C. A., Brooks, M. E., Ineson, S., Reichler, T., and Kim, J.: Analysis and reduction of systematic errors through a Seamless approach to modelling weather and climate, J. Clim., 23, 5933-5957, https://doi.org/10.1175/2010JCLI3541.1, 2010.

Matear, R. J. and Lenton, A.: Quantifying the impact of ocean acidification on our future climate, Biogeosciences, 11, 3965-3983, https://doi.org/10.5194/bg-11-3965-2014, 2014.

Morel, A.: Light and marine photosynthesis: a spectral model with geochemical and climatological implications, Prog. Oceanogr., 26, 263-306, 1991.

O'Kane, T. J., Matear, R. J., Chamberlain, M. A., and Risbey, J. S.: Decadal variability in an OGCM Southern Ocean: intrinsic modes, forced modes and metastable states, Ocean Model., 16, 1-21, https://doi.org/10.1016/j.ocemod.2013.04.009, 2013.

Oke, P. R., Griffin, D. A., Schiller, A., Matear, R. J., Fiedler, R., Mansbridge, J., Lenton, A., Cahill, M., Chamberlain, M. A., and Ridgway, K.: Evaluation of a near-global eddy-resolving ocean model, Geosci. Model Dev., 6, 591-615, https://doi.org/10.5194/gmd-6-591-2013, 2013.

Oschlies, A. and Schartau, M.: Basin-scale performance of a locally optimized marine ecosystem model, J. Marine Res., 63, 335-358, 2005.

Puri, K., Dietachmayer, G., Steinle, P., Dix, M., Rikus, L., Logan, L., Naughton, M., Tingwell, C., Xiao, Y., Barras, V., Bermous, I., Bowen, R., Deschamps, L., Franklin, C., Fraser, J., Glowacki, T., Harris, B., Lee, J., Le, T., Roff, G., Sulaiman, A., Sims, H., Sun, X., Sun, Z., Zhu, H., Chattopadhyay, M., and Engel, C.: Implementation of the initial ACCESS numerical weather prediction system, Aust. Meteor. Oceanogr. J., 63, 265284, 2013.

Séférian, R., Gehlen, M., Bopp, L., Resplandy, L., Orr, J. C., Marti, O., Dunne, J. P., Christian, J. R., Doney, S. C., Ilyina, T., Lindsay, K., Halloran, P. R., Heinze, C., Segschneider, J., Tjiputra, J., Aumont, O., and Romanou, A.: Inconsistent strategies to spin up models in CMIP5: implications for ocean biogeochemical model performance assessment, Geosci. Model Dev., 9, 18271851, https://doi.org/10.5194/gmd-9-1827-2016, 2016.

Shao, P., Zeng, X., Sakaguchi, K., Monson, R. K., and Zeng, X.: Terrestrial carbon cycle: climate relations in eight CMIP5 Earth System Models, J. Clim., 26, 8744-8764, 2013.

Takahashi, T., Sutherland, S. C., Wanninkhof, R., Sweeney, C., Feely, R. A., Chipman, D. W., Hales, B., Friederich, G., Chavez, F., Sabine, C. L., Watson, A., Bakker, D. C. E., Schuster, U., Metzl, N., Yoshikawa-Inoue, H., Ishii, M., Midorikawa, T., Nojiri, Y., Koertzinger, A., Steinhoff, T., Hoppema, M., Olafsson, J., Arnarson, T. S., Tilbrook, B., Johannessen, T., Olsen, A., Bellerby, R., Wong, C. S., Delille, B., Bates, N. R., and Baar, H. J. W. d.: Climatological mean and decadal change in surface ocean $p \mathrm{CO}_{2}$, and net sea-air $\mathrm{CO}_{2}$ flux over the global oceans, Deep-Sea Res. Pt. II, 56, 554-577, 2009.

Taylor, K. E., Stouffer, R. J., and Meehl, G. A.: An overview of CMIP5 and the experiment design, B. Am. Meteorol. Soc., 93, 485-498, https://doi.org/10.1175/BAMS-D-11-00094.1, 2012.
The HadGEM2 Development Team: G. M. Martin, Bellouin, N., Collins, W. J., Culverwell, I. D., Halloran, P. R., Hardiman, S. C., Hinton, T. J., Jones, C. D., McDonald, R. E., McLaren, A. J., O'Connor, F. M., Roberts, M. J., Rodriguez, J. M., Woodward, S., Best, M. J., Brooks, M. E., Brown, A. R., Butchart, N., Dearden, C., Derbyshire, S. H., Dharssi, I., Doutriaux-Boucher, M., Edwards, J. M., Falloon, P. D., Gedney, N., Gray, L. J., Hewitt, H. T., Hobson, M., Huddleston, M. R., Hughes, J., Ineson, S., Ingram, W. J., James, P. M., Johns, T. C., Johnson, C. E., Jones, A., Jones, C. P., Joshi, M. M., Keen, A. B., Liddicoat, S., Lock, A. P., Maidens, A. V., Manners, J. C., Milton, S. F., Rae, J. G. L., Ridley, J. K., Sellar, A., Senior, C. A., Totterdell, I. J., Verhoef, A., Vidale, P. L., and Wiltshire, A.: The HadGEM2 family of Met Office Unified Model climate configurations, Geosci. Model Dev., 4, 723-757, doi:10.5194/gmd-4-723-2011, 2011.

Uotila, P., O'Farrell, S., Marsland, S. J., and Bi, D.: The sea-ice performance of the Australian climate models participating in the CMIP5, Aust. Meteor. Oceanogr. J., 63, 121-143, 2013.

Valcke, S.: OASIS3 User Guide (prism 2-5), PRISM Support Initiative Report No 3, CERFACS, Toulouse, France, 2006.

Valcke, S.: The OASIS3 coupler: a European climate modelling community software, Geosci. Model Dev., 6, 373-388, https://doi.org/10.5194/gmd-6-373-2013, 2013.

Valcke, S., Craig, T., and Coquart, L.: OASIS3-MCT User Guide, OASIS3-MCT_2.0, CERFACS Technical Report TR-CMGC13-17, CERFACS/CNRS SUC URA No 1875, Toulouse, France, available at: http://pantar.cerfacs.fr/globc/publication/ technicalreport/2013/oasis3mct_UserGuide.pdf (last access: 16 September 2015), 2013.

Wang, Y. P. and Leuning, R.: A two-leaf model for canopy conductance, photosynthesis and partitioning of available energy I. Model description and comparison with a multi-layered model, Agr. Forest Meteorol., 91, 89-111, 1998.

Wang, Y. P., Law, R. M., and Pak, B.: A global model of carbon, nitrogen and phosphorus cycles for the terrestrial biosphere, Biogeosciences, 7, 2261-2282, https://doi.org/10.5194/bg-7-22612010, 2010.

Wang, Y. P., Kowalczyk, E., Leuning, R., Abramowitz, G., Raupach, M. R., Pak, B., van Gorsel, E., and Luhar, A.: Diagnosing errors in a land surface model (CABLE) in the time and frequency domains, J. Geophys. Res., 116, G01034, https://doi.org/10.1029/2010JG001385, 2011.

Wang, Y. P., Lu, X. J., Wright, I. J., Dai, Y. J., Rayner, P. J., and Reich, P. B.: Correlations among leaf traits provide a significant constraint on the estimate of global gross primary production, Geophys. Res. Lett., 39, L19405, https://doi.org/10.1029/2012GL053461, 2012.

Wang, Y. P., Zhang, Q., Pitman, A. J., and Dai, Y. J.: Nitrogen and phosphorus limitation reduces the effects of land use change on land carbon uptake and emission, Environ. Res. Lett., 10, 014001, https://doi.org/10.1088/1748-9326/10/1/014001, 2015.

Wanninkhof, R.: Relationship between wind speed and gas exchange over the ocean, J. Geophys. Res., 97, 7373-7382, https://doi.org/10.1029/92JC00188, 1992.

Wilson, D. R., Bushell, A. C., Kerr-Munslow, A. M., Price, J. D., and Morcrette, C. J.: PC2: a prognostic cloud fraction and condensation scheme, I: Scheme description, Q. J. Roy. Meteor. Soc., 134, 2093-2107, 2008. 
Woodward, S.: Modeling the atmospheric life cycle and radiative impact of mineral dust in the Hadley Centre climate model, J. Geophys. Res., 106, 18155-18166, https://doi.org/10.1029/2000JD900795, 2001.

Woodward, S.: Mineral dust in HadGEM2, Hadley Centre Technical Note 87, Met Office Hadley Centre, Exeter, UK, available at: http://www.metoffice.gov.uk/media/pdf/1/p/HCTN_87. pdf (last access: 12 August 2015), 2011.

Zhang, Q., Wang, Y. P., Pitman, A. J., and Dai, Y. J.: Limitations of nitrogen and phosphorous on the terrestrial carbon uptake in the 20th century, Geophys. Res. Lett., 38, L22701, https://doi.org/10.1029/2011GL049244, 2011.

Zhang, Q., Pitman, A. J., Wang, Y. P., Dai, Y. J., and Lawrence, P. J.: The impact of nitrogen and phosphorous limitation on the estimated terrestrial carbon balance and warming of land use change over the last 156 yr, Earth Syst. Dynam., 4, 333-345, https://doi.org/10.5194/esd-4-333-2013, 2013.

Zhang, Q., Wang, Y. P., Matear, R. J., Pitman, A. J., and Dai, Y. J.: Nitrogen and phosphorous limitations significantly reduce future allowable $\mathrm{CO}_{2}$ emissions, Geophys. Res. Lett., 41, 632-637, https://doi.org/10.1002/2013GL058352, 2014.
Zhang, X. Y., Friedl, M. A., Schaaf, C. B., and Strahler, A. H.: Climate controls on vegetation phenological patterns in northern mid- and high latitudes inferred from MODIS data, Glob. Change Biol., 10, 1133-1145, 2004.

Zhang, X. Y., Friedl, M. A., Schaaf, C. B., Strahler, A. H., and Liu, Z.: Monitoring the response of vegetation phenology to precipitation in Africa by coupling MODIS and TRMM instruments, J. Geophys. Res., 110, D12103, https://doi.org/10.1029/2004JD005263, 2005.

Ziehn, T., Lenton, A., Law, R. M., Matear, R. J., and Chamberlain, M. A.: : The carbon cycle in the Australian Community Climate and Earth System Simulator (ACCESS-ESM1) - Part 2: Historical simulation, Geosci. Model Dev., 10, 2591-2614, https://doi.org/10.5194/gmd-10-2591-2017, 2017. 